\title{
TRADE-MARKS, MONOPOLY, AND THE RESTRAINT OF COMPETITION
}

\author{
Sigmund Timberg* \\ I \\ INTRODUCTION
}

Patents and copyrights were decisively deprived, during the 1947 term of the Supreme Court, of their potency for commercial regulation contrary to the antitrust laws. ${ }^{1}$ Why then, should trade-marks, in so many aspects less substantial than patents and copyrights, still present antitrust problems?

Patents and copyrights have the specific constitutional blessing of the Founding Fathers; trade-marks have none. Patents and copyrights stress standards of inventiveness and artistic expression and are hallmarks of originality; they call for a high level of understanding and sagacity on the part of both their utilizers and their audience. Successful trade-marks, on the other hand, are largely matters of giving conventional forms of syllabification and ornamentation a reiteration prolonged and attractive enough to evoke a conditioned reflex on the part of their audience-the so-called consumer response. It was Judge Learned Hand, and no crusading sociologist, who said in a trade-mark case that "The art of advertising spuriously reinforced a genuine demand by the power of reiterated suggestion."2 Furthermore, a view has always been strongly held that a trade-mark is, at best, a qualified type of property, designed primarily to ward off unfair competition, rather than an independent type of property such as a patent or a copyright.

On the other hand, for large corporations desirous of promoting a monopoly or advancing a trade restraint, a trade-mark or trade name has its advantages. The trade-mark "monopoly," limited though it may be to a segment of the English language or of the art of design, is a perpetual one. Unlike a patent, a mark or name is not limited to a specific product or class of products, but can cover all products worked on or distributed by a single firm. Furthermore, in an era when the consumer is beleaguered by a host of commodities of whose production he can know nothing, he must order by ear rather than sight or touch, and a monopoly of the

- B.A. and M.A. I930, Columbia University; LL.B. 1933, Columbia University. Chief, Judgments and Judgment Enforcement Section, Antitrust Division, Department of Justice, and Special Assistant to the Attorney General. Member of the New York and United States Supreme Court bars. Contributor to legal periodicals.

This article is intended to state the personal views of the author and does not necessarily reflect the views of the Department of Justice.

${ }^{2}$ United States v. Line Material Co., 333 U. S. 287 (1948); United States v. Paramount Pictures, Inc., 334 U. S. 131 ( 1948 ).

${ }^{2}$ Shredded Wheat Co. v. Humphrey Cornell Co., 250 Fed. 960,962 (C. C. A. $2 d$ rgr8). 
only familiar or convenient way to describe a commodity to a consumer-"Worcestershire sauce" or "linoleum," for example-gives the owner of this semantic monopoly a strong competitive advantage. ${ }^{3}$ Competitors who must resort to elaborate chemical names, for example, to denote a common drugstore product like aspirin, or an industrial product like cellophane, are blocked from access to our market-minded economy. ${ }^{4}$ Furthermore, copyrights are, to all practical intents, limited to the media of mass communication and edification, and, for the bulk of American industry, patents are now concerned with relatively minor improvements in technology, at a time when American courts have been raising the level of inventiveness necessary to the validity of patents. Trade-marks and trade names, directed as they are to distribution rather than production, have thus by comparison expanded their prominence on the American industrial scene.

While the economic significance of trade-marks has thus become greater, there was not, until the beginning of 1949 , a single litigated case bearing directly on the relationship between trade-marks and the Sherman Act. Some businesses, therefore, had begun to look hopefully at the trade-mark as an affirmative defense for trade restraints which could clearly no longer be regarded as valid as an exercise of rights under patents or copyrights. Concurrently, the Antitrust Division had launched a series of cases in which the use of trade-marks was regarded as a primary and direct source of antitrust violation.

Whether trade-marks are a threat or an incentive within the American competitive system (they can of course be both) can best be gauged after we have reviewed, first, the antitrust history of trade-marks and trade names prior to the enactment of the Lanham Act and, second, the provisions of the Lanham Act possessing antitrust significance.

\section{II}

\section{Trade-marks as Direct Restraints of Trade}

It has been fashionable in the last ten years to pose the question whether trademarks are an antitrust problem, and to conclude that trade-marks per se do not involve monopoly or the restraint of competition, but that they may be reinforcing and peripheral elements of schemes for the illegal restraint of trade, the illegality of which is complete and evident before the trade-mark features of the scheme are reached. Such a conclusion may fit the actual litigation program of the Antitrust Division in the trade-mark field in the past, but it appears somewhat deficient as applied to the larger facts of social and economic life.

${ }^{3}$ Lea v. Deakin, 15 Fed. Cas. 95, No. 8,154 (N. D. Ill. 1879); Linoleum Mfg. Co. v. Nairn, 7 Ch. D. $834(1878)$.

"The chemical name for aspirin is "acetyl salicylic acid" or "monoaceticacidester of salicylicacid." See Bayer Co. v. United Drug Co., 272 Fed. 505, 510 (S. D. N. Y. 1921). Cellophane, when you come right down to it, is transparent glycerinated cellulose hydrate regenerated from viscose. Sec DuPont Cellophane Co. v. Waxed Products Co., 85 F. 2 d 75 (C. C. A. 2d.1936). 


\section{A. Trade-marks as a Direct Vehicle of Monopoly Power}

Perhaps the most striking illustration of trade-marks as a direct source of monopoly power is the situation to which American Tobacco Company v. United States ${ }^{5}$ was directed. In I947, after the Supreme Court had affirmed the criminal conviction of the three leading cigarette manufacturers of the country for violation of the antitrust laws, those three manufacturers had 84.7 per cent of total cigarette sales. The three leading trade-marked brands (one brand to a manufacturer) accounted for 80.2 per cent of the domestic market sales of cigarette tobaccos. ${ }^{6}$ After reviewing the other factors affecting competition in the tobacco industry, some students have concluded that competition will be hard to restore unless these valuable trade-marks, and the advertising expenditures in connection therewith, are in some way brought under control. The soap industry, also involving highly advertised trade-marked commodities marketed by a very few firms, may present a similar problem, since the three largest soap companies control an estimated 80 per cent of total production. ${ }^{7}$

Trade-mark protagonists contend that trade-marks promote competition by pointing to a common source of origin for all articles with the same mark, thereby enabling the consumer to make an informed choice among competitively produced or marketed articles. It is in this sense that the protection of a trade-mark is the protection of the trade-mark owner and the general public against unfair competition, and an assurance of fair competition. Inherent in such an approach is the further assumption that it is trade-mark protection which makes quality competition possible.

Professors Chamberlin and Brown do not believe that this is what actually takes place. ${ }^{3}$ They say instead that the result of effective trade-mark promotion is to differentiate the trade-marked article from other trade-marked and nontrade-marked articles possessing the same general physical and chemical characteristics and the same utility to the consumer, and to create for the trade-marked article a monopoly and an immunity from the rigors of competition. The trade-mark creates for its specific product an entirely separate market, where demand becomes inelastic and prices are established which are independent of the prices of other articles of the same class that would otherwise be competitive with it. Implicit in this analysis is the notion that, particularly in dealing with goods of a character closely approaching the fungible, the differentiation of a product accomplished by a trade-mark is necessarily spurious, because the trade-marked product is not in fact substantially different from that of other articles of the same class. The trade-mark, and the advertising

${ }^{5} 328$ U. S. 78I (1946).

- Brown, Advertising and the Public Interest, 57 YaLE L. J. I165, II73 (1948).

${ }^{7}$ Fortune, April, 1939, pp. 77, 82.

${ }^{8}$ Sec Edward Chamberlin, The Theory of Monopolistic Competition 56-70, 246-250 (5th ed. 1946); Brown, supra note 6. The reader, it is hoped, will pardon this indiscriminate merging of two distinctive approaches to the problem. The first is that of the classical economist preoccupied with whether the differentiation supplied by a trade-mark is consonant with the premises of free competition; the second is that of the lawyer-sociologist and critic of the institution of advertising. In fact, the interested reader would do well to consult both. 
attendant upon the trade-mark, create in the consumer subjective illusions and expectancies of wide but indeterminate scope, and impart an element of economic irrationality to consumer demand, which is then assumed to justify a higher price for the article. Society should not reward a trade-mark owner for such an anti-competitive, intangible, and wasteful procedure.

Views of the type just outlined project us into conflicting considerations as to the commercial morality and social utility of trade-marks, the dollar value of consumer illusions, the irrationality of consumer choices, and the role of non-price competition under the Sherman Act. Also, both implicit and explicit in the Chamberlin-Brown school of thinking is criticism of the institution of advertising. The trade-mark, whatever its intellectual significance as an indicator of who gave the trade-marked commodity its manufacturing or marketing "style," is clearly also a bearer of advertising values. In certain situations, the skillful and massed use of advertising expenditures has effectively created for a trade-marked commodity and its producer or distributor a dominant or monopolistic position. To give other manufacturers of the same commodity an opportunity to use the trade-mark would be one way of diluting the values created by such strenuous advertising; this would reduce the monopoly position of the original trade-mark owner, if it resulted in a diversion of his business to the new users of the mark. Another possible way of meeting the situation would be through the direct limitation of advertising expenditures by the monopolistically situated trade-mark owner.

Here, as with respect to the tobacco and soap situations just outlined, the writer must abstain from trying to resolve economic disputes with undoubtedly widespread social ramifications but with thus far little accompanying legal grist. Before leaving this controversial topic, however, we may note that the more conservative school of trade-mark protection (and the one which is judicially accredited), which considers the trade-mark's sole function to be that of indicating source of origin, ${ }^{0}$ is obviously less likely to be vulnerable to these strictures than those which would claim for the trade-mark a more far-reaching significance as the conservator of independent property rights created by advertising. ${ }^{10}$ However, once the courts ceased insisting that a trade-mark denote a known and particularized "source of origin" and reconciled themselves to the notion that it could signify an anonymous "source of origin," they did more than to create a metaphysical contradiction. They were

\footnotetext{
${ }^{\circ}$ Kellogg Co. v. National Biscuit Co., 305 U. S. IrI (1938); Yale Electric Corp. v. Robertson, 26 F. 2d 972, 973 (C. C. A. 2d I928); DuPont Cellophane Co. v. Waxed Products Co., supra note 4; Rooers, New Concepts of Unfair Competition Under the LANhaM Act 203 (Practising Law Institute Lecture Dec. II, I947).

${ }^{10}$ See Schechter, The Rational Basis of Trademark Protection, 40 Hanv. L. Rev. 813 (I927); Isaacs, Traffic in Trade-Symbols, 44 Harv. L. Rev. 1210 (1931). There scems to be morc cnthusiasm for this view among legal writers than among judges. To this writer, the cases still seem to favor the "source of origin" theory, although modern business conditions have deprived the source of origin of the continuity and specificity that was possible in a less mechanized world. See Mulhens \& Kropf, Inc. v. Ferd. Muelhens, Inc., 43 F. $2 d 937$ (C. C. A. $2 d$ 1930), including the dissenting opinion of Judge Learned Hand therein.
} 
at least recognizing that the differentiation accomplished by a trade-mark is not precise. Whether such a legal position is the equivalent of the Chamberlin-Brown economic position that a trade-mark does not in fact effect a differentiation of source of origin is unclear. In any event, however, the problem is of considerable commercial significance. Druggists and physicians, for example, constantly complain that the pharmaceutical manufacturers flood the market with identical products under many different brand names, thereby creating unduly heavy physical inventories for the druggist and unduly exacting mental inventories for the physician. ${ }^{11}$

Furthermore, modern industrial society is passing rapidly from the polite and leisurely days of the individual trader, whose "custom" was specifically sought by individual purchasers, to the hurly-burly of standard specifications, routinized purchasing procedures and sales pressures, and inducements largely unrelated to the essential needs of the production or distribution process. In the simple situation of the individual trader, a trade-mark served a valuable competitive function in differentiating trader Smith from trader Jones. However, as sellers and buyers alike lose their specific human identity and become corporate complexes with an unpredictable admixture of institutional and human elements, the question may well be raised whether the differentiation accomplished by a trade-mark serves any such clear-cut competitive purpose. ${ }^{12}$

As to whether a trade-mark, even in its limited rôle of indicating source of origin, is of benefit to the consumer, thoughtful judges have been skeptical. Judge Frank says that, while the trade-mark is presumed to benefit the consumer, it does not do so in fact but rather operates as a boon to the producer (and only in that respect to the competitive system) by increasing the producer's incentive to produce and sell: however, consumer benefit is a factor which the courts can take into account in deciding how far to validate trade-name monopolies. ${ }^{13}$ Judge Learned Hand has indicated, in an analogous connection, that "if buyers wish to be snobs, the law will protect them in their snobbery"14_judicial ratification of Veblen's "conspicuous consumption" theory! And Judge Frank has also pointed out that trade-marks will be protected against infringement even where the deception practiced on the consumer is to his financial advantage. ${ }^{15}$ Thus, while there has been intellectual acceptance by judges of the premises of Chamberlin's critique, they have been disinclined to do more about it than to give trade-marks a narrower and more strictly defined scope than has been given them in the past.

\footnotetext{
${ }^{11}$ MacCarteny, The Pharmaceutical Change of Life, J. Am. Pharmaceutical Ass'n (Practicar Pharmacy ED.) 672, 673 (Nov. 1948); Hardt, Product Development, Promotion and Marketing, in A. E. Smith and A. D. Herrick (Eds.), Drug Research and Development 45I, 459 (1948).

${ }^{12}$ Deep as is this author's admiration for the profound historical researches of Professor Schechter in this field, he is somewhat afraid that in the course of getting us back to the age of Damascus steel and the guild system Professor Schechter may be diverting us from the (largely disturbing) realities of this present impersonal and abstract era.

${ }^{13}$ See his concurring opinion in Standard Brands v. Smidler, I5I F. 2d 34 (C. C. A. $2 d$ 1945).

14 See Benton Announcements, Inc. v. F. T. C., 130 F. 2d 254, 255 (C. C. A. 2d 1942).

${ }^{25}$ Eastern Wine Corp. v. Winslow-Warren, Ltd., 137 F. $2 d 955$ (C. C. A. 2d 1943), cert. denied, 320 U. S. 758 (1943); see also Standard Brands v. Smidler, supra note 13.
} 
Nor will we find that the conventional legal cliché that trade-mark protection is justified as a method of preventing "unfair competition" throws any light on the question whether trade-marks promote "competition" in fact. After all, price-cutting is regarded by many as "unfair competition," yet the customary industry effort to stifle price-cutting by "chiselers" would not only be regarded as anti-competitive but usually violates the antitrust laws. What does the law of "unfair competition" mean in so far as trade-mark matters are concerned? It means that competition must be so conducted (and in the ultimate analysis so regulated) that it conforms to certain orthodox concepts of what is not unfair. At its lower level, this means that we should not resort to fraud or chicanery in the competitive struggle. In purely economic terms, the only possibility of real fraud is that the purchaser of a trade-marked article is deceived into believing that the seller of the article owns the trade-mark thereon and is the manufacturer thereof, whereas the seller is in fact neither. In legal terms, the buyer is deceived as to "source of origin" of the trade-marked article; this, it will be noted, is as far as the courts have gone in conferring trade-mark protection. In broader social terms, by giving trade-marks this type of protection, society is superimposing an ethical and moral norm on the competitive process-a norm which may be regarded as neutral as far as (orthodox) competition is concerned.

Once we try to raise the level of what constitutes "unfair competition" above the prevention of fraud and deceit, we express no longer a concept of "unfair competition" which is basic to the consumer's way of thinking, but rather concepts that are in the mind of (usually established) producers. Businessmen honestly believe that they have built up, by diligent trade-mark promotion and advertising, a good will and custom, an assurance of quality and satisfaction, that it would be "unfair" to allow their competitors to appropriate. In economic terms, they assert that they have built up a good will that they have a right to conserve and keep others from capitalizing on. In legal terms, they claim a vested interest and a property right in the good will of their trade-mark, and the right to exclude others therefrom. In broadly social terms, they are asking for an immunity from the rigors of competition and that society recognize the validity of an anti-competitive principle.

\section{B. Resale Price Maintenance through Trade-Marks}

While the purely judicial development of the law of trade-marks has not involved either the adoption or the rejection of a public policy of creating an immunized market for trade-marked commodities, the same has not been true on the legislative front. In fact, legislatures have rushed in where the judicial angels feared to tread. All except two states of the Union and the District of Columbia, through their Fair Trade Acts, and the Federal Congress through the Miller-Tydings amendment to the Sherman Act, allow the producer or the distributor of a trade-marked article to fix the resale price of that article. ${ }^{16}$ By virtue of a single contract between the owner

\footnotetext{
${ }^{20}$ See S. C. Oppenhems, Cases on the Federal Anti-Trust Laws $3^{85}$ (1948). Strictly speaking,
} 
of a trade-mark and the purchaser of the trade-marked article, the resale price for hundreds and perhaps thousands of wholesalers and retailers can be fixed. ${ }^{17}$ Absent a trade-mark and such validating federal and state legislation, the fixing of a resale price, even by one person, would be a violation of the antitrust laws. ${ }^{18}$ The MillerTydings Act is therefore recognized as an exception to the general policy of the antitrust laws and has been narrowly construed. Thus, it is applicable only where the trade-marked commodity is "in free and open competition with commodities of the same general class produced by others." ${ }^{\prime 9}$ This, of course, assumes, contrary to the economic theory we have just been discussing, that a trade-marked commodity can be and should be in a competitive market embracing other rival commodities, rather than in a separate and insulated market. ${ }^{20}$

While ostensibly a vehicle for protecting a manufacturer's marks or brands, the Miller-Tydings Act and the state statutes validating resale price maintenance contracts have been attacked as a heavily and hastily lobbied effort by established retailers and chains (particularly those in the drug trade) to maintain a level of prices and to ward off competition by so-called "pine-board independents."21 Although the exemption conferred by the Miller-Tydings Act is limited to vertical price fixing, the Act and the state legislation operating in connection with it have served as a legal subterfuge for undercover efforts by retailers to fix prices horizontally in violation of the Sherman Act. ${ }^{22}$ The Supreme Court has met this trend in an adequate doctrinal manner by holding that the right of an individual producer to make resale price maintenance contracts, or to refuse to sell to persons who will not enter into such contracts, does not authorize a combination among producers, wholesalers, or competitors to compel resale price maintenance. ${ }^{23}$ Nor can a manufacturer, say of lens blanks, use the Miller-Tydings Acts to impose resale prices on distributors who

the Miller-Tydings Act provides for resale price maintenance of articles bearing the "brand or name" of the producer or distributor, as well as those carrying his trade-mark. However, it is questionable whether the provision has any value for a producer or distributor if his competitors can "pirate" his brand or name. Accordingly, the practical result is that brands and names tend to be trade-marked.

${ }^{17}$ Professor Shuiman thinks cven this too generous a statement. He believes that the price under fair trade acts is fixed by notice, not by agreement; if this is true, then the state fair trade act may not qualify for the protection afforded by the Miller-Tydings Act. See Shulman, The Fair Trade Acts and the Law of Restrictive Agreements Affecting Chattels, 49 Yale L. J. 607, 619 (1940).

${ }^{18}$ Dr. Miles Medical Co. v. John D. Park \& Sons Co., 220 U. S. 373 (xgII).

${ }^{10}$ Eastman Kodak Co. v. F. T. C., 158 F. $2 d 592$ (C. C. A. 2 d 1946), cert. denicd, 330 U. S. 828 ( 1946$)$.

20 "Hence it will not do to say that all film is in the same class. If a purchaser wants a color film, he must be able to buy it from more than one manufacturer if there is to be 'free and open competition with commodities of the same general class'; that he can buy a black and white film will not serve to destroy the monopoly of the sole producer of color film." Circuit Judge Swan in Eastman Kodak Co. v. F. T. C., supra note 19 , at 594 .

${ }^{21}$ Memorandum by Corwin Edwards, in Final Report and Recommendations of the Temporary National Economic Committee 232 et seq. (194I); Shulman, supra note I7, at 6r6-6i7.

${ }_{22}^{2}$ See United States v. Food and Grocery Bureau of Southern California, Inc., 43 F. Supp. 974 (S. D. Calif. r942), $a f^{\prime} d, 139$ F. $2 d 973$ (C. C. A. 9th 1943); California Retail Grocers and Merchants Association, Ltd. v. United States, I39 F. 2 d 978 (C. C. A. 9th 1943), cert. denied, 322 U. S. 729 (1944).

${ }^{23}$ United States v. Frankfort Distilleries, 324 U. S. 293 (1945). 
sell a processed version of the finished article, i.e., finished lenses."2 Furthermore, even where resale price maintenance contracts are valid in and of themselves, they will be canceled if they are a "patch upon an illegal system of distribution."25 Waiving any issue as to the desirability of the Miller Tydings Act per se, ${ }^{202}$ and sound as the Supreme Court has been in guarding against that statute's abuse, the question may therefore well be raised whether the use of a trade-mark or brand in resale price maintenance contracts does not have economic consequences inconsistent with the basic premise of the Sherman Act. ${ }^{26}$

\section{Trade-marks as a Monopoly of Language}

When we come to the area where allowance of a claim for trade-mark protection becomes, in the language of Judge Freed, "tantamount to the gift of exclusive ownership of the use of an English word,"2r we run into some very serious problems indeed. Let us distinguish simply between what I shall call generic and specific symbols. A generic symbol signifies-in the sense of uniquely pointing to or denoting -either a class of products or a general quality of a product (in trade-mark parlance, generic or descriptive names), e.g., "cola," "white." A specific symbol symbolizes-in the sense of more or less equivocally evoking or connoting-the maker or merchandiser of an article, the larger corporate complex in which the individual maker or merchandiser is a submerged unit, the particularly melodious crooner or effective radio saga sponsored by the corporate complex, or some specific quality, sensation, or emotional association attributed to the symbolized article, ${ }^{28}$ e.g." "U. S. S., "Swan" (for soap), "Lyons" (for tooth powder).

It would be incongruous for a competitive distributive economy to allow any single legal individual to appropriate exclusive rights over general symbols. If manufacturers or traders are foreclosed from naming the product they are trying to market or from describing its qualities, they are effectively and completely debarred from access to the market. It is, therefore, sound for the courts to hold that the

${ }^{24}$ United States v. Univis Lens Co., 316 U. S. $24 \mathrm{r}, 252$ (1942).

${ }^{25}$ See United States v. Bausch \& Lomb Optical Co., 321 U. S. 707, 724 (I944).

25a The Federal Trade Commission, the Antitust Division, and numerous consumer and farm groups have expressed opposition to the Miller-Tydings Act and state resale price maintenance legislation. In fact, most manufacturing groups are indifferent or negative with respect to these laws; it is mainly those manufacturers that are confronted with cohesive and persistent wholesale and retail distributor associations which are following the path of resale price maintenance. See Report of Fedenal Trade Commission on Resale Price Maintenance (1945); Assistant Attorney General Herbert A. Bergson, Current Problems in the Enforcement of the Antitrust Law, address before the Association of the Bar of the City of New York, Feb. 17, 1949; H. R. 4003, 81st Cong., Ist Sess., introduced April 4, 1949 (calling for repeal of the Miller-Tydings Act); MacGregor, "Fair Trade" Laws Seen Losing Favor, N. Y. Times, May 22, 1949, \$3, p. x, col. 3; Review and Outlook, Wall Street Journal, May 12, 1949, p. 4.

${ }^{28}$ Resale price contracts are currently used primarily in the drug, cosmetic, toilet goods, liquor, gasoline, and book-selling fields, and more occasionally in the sale of houschold appliances, sporting goods, foods, clothing, rubber products, radios, and tobacco. Report of Federal Trade Commission on Risale Price Maintenance lvi (1945).

${ }^{27}$ Majestic Mfg. Co. v. Majestic Electric Appliance Co., Inc., 76 U. S. P. Q. 525,526 (N. D. Ohio 1948).

${ }^{28}$ A more detailed enumeration of different meanings of a trade-mark in legal writings is to be found in Isaacs, Traffic in Trade-Symbols, 44 Harv. L. REV. I210, 1220 (193I). 
public domain of the English language may not be pre-empted and that no trademark rights inhere in generic symbols like "argyrol" or "red." It is also sound commercial practice for trade-mark counsel to urge their clients to choose artificial and meaningless names, rather than names with possible descriptive connotations. ${ }^{29}$ However, the advice of advertising men runs counter to that of trade-mark counsel, and, therefore, businesses frequently adopt trade-marks that are generic symbols, i.e., marks that name or describe general types of products.

The courts, using common law and common sense, have theoretically been the best protectors of the general public and of competitors against the exclusive appropriation by any one person of words necessary to name or describe articles of commerce. It is only occasionally that this protection is accorded in an antitrust proceeding. Thus, in United States v. Albany Chemical Company, the defendant was charged with conspiring with the Trade Mark Title Company to violate the Sherman Act by fraudulently registering with the Secretary of State of New York as its exclusive trade-mark the mark-mirabile dictu-"aspirin," and intimidating competitors by threatening suits for the infringement of that mark. ${ }^{30}$ Usually, the judicial protection flows from a sober analysis of the function of trade-marks. By insisting that descriptive and generic marks be open to the public, giving laudatory and honorific marks a limited protection, and curbing the trend to have a person protected in his trade name or trade-mark even for articles he does not produce nor intend to produce, the courts have implicitly recognized that a monopoly of a facility of mass communication such as a trade-mark may promote trade restraint as effectively as a monopoly of a facility of mass commodity transportation like a stockyard or a rail terminal. ${ }^{31}$ The difficulty with the courts is that while their general philosophy of the law and function of trade-marks is intelligent and forward-looking, their resolution of specific trade-mark disputes is frequently somewhat murky and oracular, and too deliberative and time-consuming to aid a small businessman without trade-mark protection and without the resources to do legal battle against an entrenched owner of a trade-mark.

There is a further difficulty inherent in the nature of language, and specifically of the English language. The English vocabulary is, as everyone knows, one of the most grasping, expansive, and flexible in the world; there are no Forty Immortals, as in France, to ban the entry of the jejune and immature word. A great part of the growth of the English language, unlike Continental languages, is due to its ready assimilation of trade names, the invention of which, at least in 1919, was "not

${ }^{20}$ See Liddy, Trademarks from Manufalcturers' and Retaillers' Points of View 47-48 (Practising Law Institute Lecture, Nov. 6, 1947); Handler, Trademarks and the ANTItrust Laws 229 (Practising Law Institute Lecture, Jan. 8, 1948).

${ }^{30}$ Eq. No. 20-232, S. D. N. Y., settled by final decree entered Jan. xo, I921.

${ }^{\text {ax }}$ Cf. Associated Press v. United States, 326 U. S. I (I945) (press news) with Swift and Co. v. United States, I96 U. S. 375 (1905) (stockyards) and United States v. Southern Pacific Co., 259 U. S. 214 (Ig22) (railroad terminals). 
a customary procedure on the part of foreign advertisers."32 Names of so-called fanciful origination are continually in process of becoming commonplaces of conventional description, and in fact are frequently the only way of describing certain products, as in the pharmaceutical industry (mercurochrome, aspirin).

In short, specific symbols, even those of a most arbitrary nature, are continually being given broader coverage and transmuted into generic symbols. Within a generation, the mark "cola" had traversed the road from specificity to genericness. ${ }^{33}$ It is a frequent consequence of the promotion of even an unfamiliar trade-mark or trade name that it becomes an indispensable way of describing the trade-marked product; in fact, it is a consequence frequently intended by enterprising sales departments. However, the determination of when a word has become incorporated in a language as a descriptive or generic term is necessarily a subjective and statistical one. Paradoxically enough, names which the Pure Food and Drug Administration considers "common or usual," so that under its labeling statute it requires persons manufacturing or marketing a food or drug to identify it by that name on the label, may nevertheless not be considered "common descriptive names" under the Lanham Act. ${ }^{34}$ Also, this a field where appellate judges seem to attach little weight to the factual determinations of a trial court; with apparently complete abandon they reach for the encyclopedia or resort to the direct questionnaire technique. ${ }^{35 t}$ Under the circumstances, therefore, the owner of a trade-mark who has, by his own investment and labor, built it up into familiarity may well be pardoned a reluctance to concede it that degree of familiarity which would deprive him of his hard-earned good will and result in dedicating the mark to the public. Dr. Vizetelly, the lexicographer, has pointed attention to the characteristic schizophrenia of manufacturers who sponsor a product that is winning popular acclaim: first they court a place for the trade-mark in the dictionary; then they try to remove it to keep it from becoming over-popular. ${ }^{36}$

${ }^{32}$ See Brander Matthews, The Advertiser's Artful Aid, 48 Bookman 659, 662 (1918-1919). Paradoxically, however, words like "Kodak" and "Vaseline," while held down to trade-mark status in the United States and England, have entered most continental languages. Sce HENRY L. MENCKEN, ThE American Language 172-173 (4th ed. I938); id. Supp. I, 342 (1945).

${ }^{33}$ See Coca-Cola Co. v. Standard Bottling Co., 138 F. $2 d 788$ (C. C. A. Ioth 1943), upholding the reopening of a constant decree to permit a hitherto debarred defendant to use the word. Another cxample is "Zipper," which was coined by B. F. Goodrich Company in 1913, registered by it in 1925, upheld in 1930; see B. F. Goodrich Co. v. Hockmeyer, 40 F. $2 d 99$ (C. C. P. A. 1930). Goodrich still claimed it as a trade-mark in the footwear field in 1944, but Life magazine (which should be an outstanding authority on this subject) said in 1938 that it had passed into the English language. It is hard to appreciate that "Singer" was once the generic name denoting sewing machines. See Singer Mfg. Co. v. June Mfg. Co., I63 U. S. 169 (I896); or that "Goodyear Rubber" was a descriptive name describing, of course, Goodyear's invention. See Goodyear's India Rubber Glove Mfg. Co. v. Goodyear Rubber Co., 128 U. S. 598 (1888); or that one of the first labels for gasoline was "petrol." See Hutton, Get Out and Get Under-Motoring Fifty Years Ago, Atlantic Monthly, Nov. 1948, pp. 40, 42.

${ }^{34}$ Derenberg, The Lanham Trademark Act and Its Impact on the Drug Indistry, 37 T. M. Rep. 392 (1947); Derenberg, Some Unique Features in the Selection and Protection of Pharmaceutical TradeMarks, 4 Food, Drug and Cosm. L. Q. 137 (1949).

${ }^{35}$ Frank, J., dissenting in La Touraine Coffee Co. v. Lorraine Coffee Co., 157 F. 2d 115, 120 (C. C. A. 2d 1946), cert. denied, 329 U. S. $77 \mathrm{I}$ (1946); Frank, J., dissenting, in Triangle Publications v. Rohrlich, 167 F. 2d 969, 976 (C. C. A. 2d 1948).

${ }^{30}$ Sce Vizetelly, Pillaging the Language, I50 Atzantrc Montrny 228-234 (1932). If the Hawles Bill, S. 19r9, passes, dictionary publishers will think twice before they rashly insinuate that a registered mark has become a part of English speech, because they will render themselves subject to a cause of action by the trade-mark owner for any careless attribution of genericness to such a mark. 
Thus it often becomes worth the trade-mark owner's while to insist on a thorough judicial ventilation of the issue of genericness-a ventilation which blows down all competitors but those possessed of the financial capacity for enduring slow, costly, and uncertain litigation. Entrepreneur $A$, who has invested a great deal of advertising in a mark and by his diligence and exertions converted unfamiliar words or phrases like "aspirin" and "shredded wheat" into household words, quite naturally resists the factual inferences and legal conclusions, based on his promotional success, that deprive him of the fruits of his labors. Newly arrived businessman $B$, who wants to enter a market and feels he is doomed to failure unless he too can use the magic password, understandably enough feels that the alleged mark is an indispensable part of the common argot. Given equally strong convictions and resources, the dispute is settled only by protracted judicial proceedings entailing long delay and unpredictable expense and outcome. In the majority of cases, the nouveau arrive does not have the resources or stamina to withstand these legal and judicial rigors. It may be most gratifying to find out that "Shredded Wheat" has been in the public domain since I912; but how many small businesses can take the necessary gamble of possible defeat and pay counsel and court fees from I912 to 1938 , when that determination was finally and authoritatively made ${ }^{37}$

\section{Summary}

In retrospect, therefore, trade-marks, in addition to their role as facilitating or enforcement mechanisms for competitive restraints independently desired by private parties, may directly promote restraint of trade. Thus, for example, trade-marks may on occasion be the direct vehicles whereby monopoly power is consciously brought to bear on actual or potential competitors. Furthermore, protagonists of classical competitive theory urge that trade-marks undermine the proper basis of competition contemplated by the antitrust laws, because the demand for a trade-marked commodity persists and is inelastic, regardless of what is attempted by would-be competitors in the way of ordinary price competition. In other cases, owners of trademarks or trade names become unconscious, albeit willing, monopolists because the trade-marks or names are indispensable means of describing commodities in the market place. It may well be that these direct, and perhaps often unintended, consequences of the use of the trade-mark are socially more important than the positive and purposive use of trade-marks to abet illegal conspiracies. Allied with these considerations is the fact that the functioning of the trade-mark system may place small business at a great relative disadvantage compared with big business, and may thereby promote the concentration of economic power in this country faster than antitrust proceedings in the trade-mark freld can dissipate such concentration.

In the foregoing discussion we have been talking about mixed commerciallinguistic developments that need not necessarily result in a strictly demonstrated

\footnotetext{
${ }^{37}$ Kellogg Co. v. National Biscuit Co., 305 U. S. III (1938). The basic design patent expired in 1912. However, Shredded Wheat has been known to the public since 1894, and the mark had been denied registration in 1905.
} 
antitrust violation, but which may nevertheless involve serious competitive disadvantages for small and new business. This theme of small-business ${ }^{38}$ disadvantage will be elaborated when we discuss the Lanham Act later on.

\section{III}

\section{Trade-Marks as Facilitating Restraints of Trade}

\section{A. Division of Territories}

Most of what has thus far been written about trade-marks and restraint of trade has to do with the use of trade-marks to help maintain illegal international cartel arrangements. The typical arrangement is one whereby concerns in different countries, by agreement, use a common trade-mark, but only one concern has the use of the mark in any one country. That concern is therefore able, by enforcing or threatening to enforce the trade-mark through judicial infringement proceedings and before the customs authorities, to exclude other concerns from its own home markets and from other areas where it has the exclusive right to the mark. The reader would do well to consult the prior literature for a more detailed treatment of how the mark "Plexiglas" in the field of acrylic plastics, the name "Merck" in the field of chemicals and pharmaceuticals, the New Jersey Zinc trade-mark in the zinc field, and the mark "Mazda" in the electric lamp industry helped reserve American markets for American firms free of competition from foreign firms, and curtailed the export trade of this country for those industries. ${ }^{30}$

Those who urge that it is not the trade-mark but the antecedent contractual arrangements and intentions of the parties that produce the trade restraint are only partially correct. In the first place, it is notorious that parties to contracts repent thereof, frequently try to extricate themselves therefrom, and often succeed. . A firm which has agreed not to compete for a foreign market may be able to repudiate that agreement, particularly if it happens to be an American firm that is violating its

\footnotetext{
${ }^{38}$ The following two quotations from Time relate to a lawsuit which Philadelphia's Fayctte $\mathbf{R}$. Plumb, Inc, recently won in the Los Angeles District Court against the Los Angeles Plomb Tool Company (named after Alphonse Plomb, one of the three founders of the firm). Los Angeles Plomb applied in 1926 to make its name a trade-mark, but was met by a protest by Philadelphia Plumb. In March, I947, a Federal district court gave Los Angeles Plomb a year within which to stop using and advertising its name (Plomb) as a trade-mark. At the beginning of December, 1948, the district court "ordered Plomb of Los Angeles to: (I) fulfill last year's order at once, and (2) pay Plumb of Philadelphia all the profits it had made since March 1948 on sales of tools marked 'Plomb.' To comply, Plomb had to close down. Frantically appealing from the decision this weck, the company estimated that it would take at least four months, and cost around $\$ 1,000,000$, to change over to a new trademark. In that time, said Plomb, its markets and most of its skilled help would be gone. In addition, the company estimated that it would have to pay $\$ 500,000$ in profits to Plumb and $\$ 40,000$ in costs, a loss that would be sorely felt. It looked as if tool buyers might never again be confused over Plomb and "Plumb." Time, Dec. 6, 1948, p. 94.

About six weeks later the Los Angeles" company opened with a new trade-mark. "Plomb President Morris Pendleton, who is appealing the decision, said the new trade-mark was just a temporary expedient (estimated cost: $\$ 130,000)$ to resume business. 'We have been handed a lemon,' said he, 'so we are making lemonade." "Time, Jan. 27, I949, p. 84 .

${ }^{30}$ See Diggins, Trademarks and Restraints of Trade, 32 Gro. L. J. Ir3 (1944); Borchardt, Are Trademarks an Antitrust Problem? 3I GEo. L. J. 245 (1943).
} 
own domestic law and public policy by such an agreement. However, if that same American firm binds itself to use a mark that is registered abroad in the name of a foreign competitor, that foreign competitor is able to exclude the trade-marked products of that American firm in perpetuity, so that the American firm has made an irrevocable election to stay out of the foreign market. In other words, the often weak contractual sanctions underlying agreements not to compete become reinforced by the stouter sanctions of trade-mark infringement and customs barrier. ${ }^{40}$ As frequently happens with secondary and later-contrived defenses, they become stronger than the original defense.

One may ask: Why cannot the American firm use another trade-mark for its export business? The answer lies both in the distribution procedures and in the technology of the industry involved. In some cases, such as ball bearings and storage batteries, the trade-mark is actually stamped into the metal of the product, so that expensive re-tooling operations might be involved. ${ }^{41}$ In practically all cases the entire promotional and distributional system of a firm is geared to one or two trade-marks. Advertising is international in scope, and one of the great advantages of having a single trade-mark is the intrinsically multilingual and universal character of the mark. To duplicate, for an entirely new mark, the advertising, packaging, and handling expenses and the lengthy development period that went into establishing the good will behind an old and established mark would place the company at a great competitive disadvantage. Furthermore, in many cases, debarment from the use of the trade-mark that has had world-wide acceptance over a long period of years (so that it has almost become generic) may be a wellnigh insuperable economic hazard.

Furthermore, private parties who execute ordinary cartel agreements can only bind themselves to stay out of each other's territory; they cannot thus bind their customers or other third parties not privy to their agreement. Where, however, manufacturers are dealing with a trade-marked product, such as, let us say, magnetos, arrangements made by them for the exclusive use of trade-marks in certain countries would exclude not only the manufacturers themselves, but also any distributors, dealers, or exporters handling their product. Those interested in the freedom and growth of our export business will therefore be particularly interested in guarding against trade-mark restrictions that promote an international division of territories.

It may be of some interest to inquire what relief is possible and has been obtained

${ }^{40}$ Sce $\$ 1526$ of Tariff Act of 1930, 46 STAT. 74I, 19 U. S. C. $\$ 1526$ (1946). This statute is applicable even to articles imported for personal consumption. Sturges v. Clark D. Pease, Inc., 48 F. $2 \mathrm{~d}$ 1035 (C. C. A. 2d I93I). It is immaterial, of course, whether an illegal division of territories or agreement not to compete is consciously reinforced by concurrent trade-mark use by the partics or whether, either before or after such unadorned illegal agreement is consummated, the parties independently build up trade-marks in their own territories that make subsequent competition impossible. World economic Balkanization is the outcome in cither event.

'T The example has been supplied of a tire balancer, where the stamped trade-mark had a substantial effect on the balancers. See testimony of Elliott H. Moyer in Hearings before the Subcommittee on Patents on H. R. S2, 78th Cong., 2d Sess. 73 (1944). 
against the illegal division of territories by trade-mark. ${ }^{42}$ It is, of course, elementary that all illegal cartel agreements based on or involving trade-marks will be canceled, their revival or renewal enjoined, and the defendant enjoined against refraining from competition for any market covered by a trade-mark allotted to a cartel partner. ${ }^{43}$

During the war, it was recognized that the economic activity of German private business was directly harnessed to the war-making activities of the German government, and that "spearhead" concerns like Bayer, Merck, Schering, and SiemensSchuckert kept alive not only German economic influences in Latin American countries but also promoted Nazi thinking and German political support. It was therefore one of the aims of Allied economic warfare that these German spearhead concerns be eliminated from those countries; and it subsequently became part of the post-war program for the elimination of German economic-military potential abroad that the old German industrial connections in Latin American and other non-Axis countries not be re-established. ${ }^{44}$ In situations where American and German firms shared the same trade-mark, but the mark in South American countries was registered in the name of the German firm, the American firm exporting the trade-marked product was obviously excluded from the South American market. When, during the war, an American firm continued to export trade-marked products to a South American country under the mark registered in the name of its German cartel associate, the net effect was to keep alive for that cartel associate a market which the American firm might otherwise have pre-empted. To meet this situation, consent judgments have therefore been entered enjoining the American defendant from reserving, or undertaking to reserve, for a foreign cartel partner any right or immunity to use or control the use in any market or country of any trade-mark, trade name, or other designation in use by the American company. ${ }^{45}$ From the foregoing it seems clear that the problem of preventing international division of territories by trade-mark continues to be, in cases where a German firm is involved, not only a problem of promoting the general freedom of international trade but also one of preventing Germany from re-arming and of insuring the security of the world.

\footnotetext{
4The relief obtained by the Antitrust Division against trade-mark abuse has thus far been secured by consent judgment. It may be noted that the usual injunctive provisions against allocation of territories and the impeding of exports or imports applicable to illegal international agreements based on patents are applicable to similar illegal agreements based on trade-marks. Cf. Art. IV of Final Judgment in United States v. General Electric Co. (D. N. J., Civ. Actions Nos. 1364 and 2590, entered March 7, 1946).

${ }^{13}$ See Arts. III and VI(G)(2) of Final Judgment in United States v. Merck \& Co. (D. N. J., Civ. Action No. 3159, entered Oct. 6, 1945).

"For a statement of the American Government's so-called economic warfare (replacement) and safehaven (postwar economic disarmament) policies, see testimony of Assistant Secretary of State William T. Clayton in Hearings before the Subcommittee of the Senate Committee on Military Affairs, pt. 2, 79th Cong., Ist Sess. 39 et seq. (1945). The story of how I. G. Farben functioned as an instrument of economic espionage and warfare is set forth in Part 7 of the Hearings at pp. 947-953, 992-1002.

45 Art. VI(c) of Final Judgment in United States v. Merck \& Co., stupra note 43; Art. VI(c) of Final Judgment in United States v. Rohm \& Haas Co. (E.D. Pa., Civ. Action No. 9068, entered Nov. 18, 1948).
} 
Relief against trade-mark abuse is, of course, justified on the ground that it is necessary to dissipate the effects of the abuse. However, it should derive additional sanction from the fact that the abuse of a monopolistic privilege granted by law results in the forfeiture, or the lessening, of that monopolistic privilege. This general principle has been followed in the case of patents; ${ }^{46}$ there seems to be no apparent reason why a similar result should not attach in the case of that more tenuous claimant to monopoly status-the trade-mark.

Relief obtained against international division of territories by trade-mark has also included enjoining a defendant from conditioning any right or immunity under a trade-mark upon a covenant, agreement, or understanding not to sell, or permit the sale of, products for export or import in the United States, ${ }^{47}$ or from reserving or granting to any person the right or power to prevent or restrict imports into any country by giving such person the right or power to control trade-marks, trade names or other designations used by the defendant. ${ }^{48}$ Similarly, a defendant may be enjoined from requiring any person to restrict the trade-marks, trade names, or other designations used in connection with products of the type manufactured by the defendant to trade-marks, trade names, or designations owned or controlled by the defendant in foreign markets. ${ }^{49}$

Of probably greater efficacy are provisions whereby the defendant gives up completely its own use of specified trade-marks or names in connection with its products or business, and engages not to maintain any trade-mark infringement proceedings or take any other steps to prevent any person from using the marks or names thus relinquished. ${ }^{50}$ Such a surrender facilitates imports by foreign competitors of the American trade-mark owners both into this country and into other countries where the American firm had prior trade-mark protection. In order to facilitate exports by American firms into countries from which they had hitherto been excluded both by intention and by trade-marks, a recent consent judgment provides that the defendant

take such steps and do such things as will eliminate any interference because of the trademarks or trade names used therewith, with the importation of any such type, line or classification of electric storage batteries into such country or area. Such steps may include, without limitation, the making available of electric storage batteries which do not bear, to the defendant's knowledge, infringing trademarks or trade names, the preparation and dissemination of appropriate trade literature, and changes in the methods of packaging and handling. 51

\footnotetext{
${ }^{10}$ Morton Salt Co. v. Suppiger, $3{ }_{4}$ U. S. 488 (1942); Mercoid Corp. v. Mid-Continent Investment Co., 320 U. S. 66I (1944); Hartford Empire Co. v. United States, 323 U. S. 386 (I945).

$"$ Art. V(c) of Final Judgment in United States \% Electric Storage Battery Co. (S. D. N. Y., Civ. Action No. 31-225, entered Nov. 24, x947).

${ }^{48}$ Art. XII(a) of Final Judgment in United States v. Electric Storage Battery Co., supra note 47.

${ }^{\circ} I d$. Art. XII(b).

${ }^{50}$ Art. XIII of the Electric Storage Battery judgment, supra note 47, applies this rule to five trademarks owned by the Electric Storage Battery Company. Also, Chloride Electrical Storage Battery Co., Ltd., was authorized by the judgment to use its name in this country, a use which had hitherto been barred by the existence of a trade-mark in this country owned by Electric Storage Battery Company.

${ }^{21}$ Id. Art. XI. See also similar language in Art. VI(B) of Amended Final Judgment in United States v. American Bosch Corporation (S. D. N. Y., Civ. Action No. 20-164, entered June 4, 1948).
} 
Another recent consent judgment takes care of both export and import situations by enjoining the defendant from assigning or granting to its German, English, and French cartel partners, or to any other manufacturer or distributor of Bosch products located outside of the United States, any exclusive license for any country of the world in or to any trade-mark or trade name. ${ }^{52}$ The same defendant was also enjoined from interfering with or preventing, by trade-mark infringement proceedings or other actions based on trade-mark or trade-name rights, any foreign business manufacturing, selling, or distributing Bosch products from importing those products into the United States under any name or designation rightfully attached to such products, provided the importing firm takes appropriate steps to prevent confusion of those products with those produced by American Bosch. ${ }^{53}$ Probably the most direct way of freeing the American export trade from trade-mark restraints would be for a defendant to adopt a policy of selling to exporters either an untrade-marked product or a product bearing a different trade-mark from those reserved to the defendant's cartel partners in foreign countries.

Situations in which trade-marks figure in illegal international divisions of territory frequently also involve either distributors in a foreign country exclusively devoted to the sale of a cartel competitor's product or common distributors who may exhibit a strong preference for a fellow cartelist's product. Also present in the situation where cartel associates share a common trade-mark is a practice on the part of the American defendant company of referring orders which emanate from a market reserved by agreement and trade-mark arrangements for a foreign competitor, to that foreign competitor for fulfillment. ${ }^{54}$ Injunctions have been obtained in recent consent judgments against these additional objectionable features of the international distribution of trade-marked products. ${ }^{55}$

The current scope of the international trade-mark and cartel problem is well delineated in the Government's recent proceeding against the Timken Roller Bearing Company, decided by Judge Freed on March 3 of this year. ${ }^{\text {to }}$ Since Igog, world markets for tapered roller-type bearings, one of the most important types of antifriction bearings, have been divided between the Timken Roller Bearing Company (American Timken) and a British concern, and competition therein has been eliminated. As a result of agreements more recently entered into, in 1928, I934 and 1935, and 1938 , the entire world market for tapered roller bearings is divided into four

${ }^{52}$ Art. $\mathrm{V}(\mathrm{A})(\mathrm{f})$ of Amended Final Judgment in United States v. American Bosch Corporation, supra.

${ }^{53}$ Id. Art. $\mathrm{V}(\mathrm{A})(\mathrm{h})$.

"see, e.g., the complaint in United States v. SKF Industries, Inc. (N. D. Ohio, Civ. Action No. 24215), and United States v. Norma-Hoffman Bearings Corporation (N. D. Ohio, Civ. Action No. 24216).

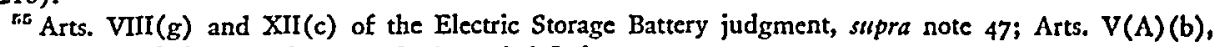
(d), and (e) of the American Bosch Amended Judgment, supra note $5 \mathrm{x}$.

${ }^{50}$ United States v. Timken Roller Bearings Co., 83 F. Supp. 284 (N. D. Ohio 1949). Compare also the complaints in United States v. SKF Industries, supra note 54 (roller bearings); United States v. The Permutit Company (S. D. N. Y., Civ. Action No. 32-394) (water conditioning and purifying equipment and materials); United States v. Decea Records Co. (S. D. N. Y., Civ. Action No. 46-779) (phonograph records). 
areas: (I) the British Isles, the British Empire (except Canada), and Europe (except France and Russia), which are allocated to the British company; (2) France and the French colonies and protectorates, which are allocated to a French concern; (3) Russia, which is the joint territory of both Timken and the British company; and (4) the rest of the world, including the United States, which is allocated to American Timken. Sporadic sales were made by the co-conspirators in each other's territories, but only to forestall outside competition. The agreements dividing foreign territories and fixing prices in world markets prior to 1927 had ostensibly been based on patent licenses. In time the significant patents expired; yet the restraints continued.

Although the agreements and sale practices of the parties and a continuing exclusive interchange of technological information, patented and unpatented, still buttress the division of territories obtaining among Timken and its foreign cartel associates, the Government pressed the view that the Timken name and marks are probably by now the most solid reinforcement behind the anti-competitive understanding of the parties. The defendant, on the other hand, attempted to defend the attacked arrangements on the ground that they were ancillary to the licensing of trade-mark rights. Under the agreements, the British and French companies are prohibited from manufacturing, selling, or dealing in bearings except under the name "Timken." This of course prevents them from building up good will in any other mark and thus from creating competition, because the parties to the agreement can employ trade-mark infringement suits and detention by the customsauthorities as legal weapons to prevent any importation of "Timken" bearings into areas reserved to them. Not only must the co-conspirators put all their distributional and promotional eggs into Timken's basket; they automatically lose both the eggs and the basket if they do not renew their present agreements not to compete. Upon the termination of the present agreements, the British and French companies are obligated to eliminate "Timken" from their corporate name, to refrain from using it, and, in so far as practicable, to assign to American Timken their rights in the Timken name. Since the good will of the co-conspirators has been completely focused on the Timken trade-mark for the past thirty-nine years (and will be for a total of fifty-six years if the the present agreements are allowed to run out), the Government contended that the co-conspirators had a veritable Hobson's choice between destroying their business and terminating their illegal cartel arrangement.

It was also stressed in the Government's brief that the American defendant and its foreign cartel associates have not only refrained from direct shipments into each other's territories, but they have dissuaded importers, exporters, distributors, automobile dealers, and others from buying bearings from one cartel partner and reselling those bearings in the territory of a different cartel partner. Furthermore, since the British and French companies are prohibited from dealing in bearings under any other mark than "Timken," and the defendant Timken Company is the only 
company that can make roller bearings thus marked in the United States, Timken's domestic competitors, as well as their distributors or dealers, are completely foreclosed from supplying any demands which the British and French companies might have for American-manufactured ball bearings. The rival American manufacturers are much smaller than Timken, and yet they must compete individually against the combined world-wide advertising and promotion of Timken products by Timken and its British and French cartel associates, who are three of the largest manufacturers of tapered roller bearings in the world. Furthermore, since users customarily replace worn-out or defective bearings with bearings of the same make, Timken and its foreign cartel associates have a very great advantage over outside competition in securing the market for replacement of bearings originally installed by them. Finally, as far back as 1926 and 1927 , counsel was informing the defendant that the Timken name in England "has been frequently used in a context which suggests that it describes a type of bearing rather than trade origin," and "in Germany we understand that 'Timken' is more or less equivalent to 'tapered." " On this basis, the Timken trade name's potentiality for excluding competitors from international trade was undoubtedly magnified, for whoever had the right to use it had the right to use a generic name.

The defendant, according to the Government, was able to achieve this exclusionary position despite the fact that the Timken mark was so weak that it is allegedly unregistrable under the Trade-Mark Act of 1905 and on the principal register provided for by the Lanham Trade-Mark Act of 1946 . In fact, the mark is not even registrable, as such, on the supplemental register provided for by the Lanham Act. Furthermore, as Judge Freed's opinion recognized, Timken has never had worldwide rights in the name "Timken," by virtue of either registration or actual user, but on the contrary for almost forty years has foreclosed itself almost completely from using the name in many important markets of the world. Add to this that "Timken" was already recognized as a generic or descriptive name in some important commercial countries. Moreover, because of the concurrent use of the same mark by the defendant and its British and French co-conspirators, the purchasers of "Timken" bearings run a good chance of being deceived as to whose bearingsTimken's, or the British or French company's-they are actually getting. Accordingly, it would appear that it is not the legal strength of a trade-mark, but its economic maneuverability, that gives it potency.

Judge Freed's negativing of Timken's trade-mark licensing defense was unequivocal. He pointed out that, by virute of Timken's earlier agreements not to compete, it did not own, had not registered, and could not use the "Timken" mark in a great portion of the world. Necessarily, Timken could not license what it did not own. Also, the trade-mark's function was to distinguish the goods of one seller from those of another, thereby safeguarding his good will and protecting the pub- 
lic from deception. The trade-mark was not a right in gross, and could not be made a "tool to circumvent free enterprise and unbridled competition."5T

\section{B. Division of Fields}

Cartel partners can be limited not only territorially but also as to fields of production. When two firms engage in business involving commodities which are not of the same descriptive properties, the use of the same mark by both firms would prevent either from expanding into the field of trade of the other. ${ }^{58}$ Thus I. G. Farben has limited the use of the "Agfa" trade-mark in the United States by General Aniline and Film (and its predecessor companies) to the photographic film industry, while it has used the mark on a host of industrial products, including artificial threads and fibres, dyes, medicines, pharmaceuticals, perfumes, and even cocoa and chocolates." Similarly Bayer Company's use of the "Bayer" and Bayer Cross marks was not only restricted by I. G. Farben to the United States, Canada, United Kingdom, Ireland, and Cuba, but, even within Bayer Company territory such as the United States, I. G. Farben reserved the right to use those marks on dyes and dyestuffs. ${ }^{60}$ This latter commercial limitation becomes peculiarly inhibiting and stultifying when one considers the increasing scientific intertwining between sulfa drugs and sulfa dyes. What possible public interest inheres in having the same mark used by the one company on sulfa drugs and by the other on sulfa dyes? Or in having scientific research stop at an artificial commercial frontier, merely because the use of a commercial label stops at that frontier?

\section{Division of Markets and Discriminatory Pricing}

Not only-may a trade-mark pattern illegally divide territories and fields of production, but it may promote a division of markets and a discriminatory treatment of those markets that may run afoul of the antitrust laws. In the usual case, that discrimination takes the form of differential price treatment. Thus, in United States $v$. Rohm and Haas, the identical molding powder, methyl methacrylate, was sold for general construction and manufacturing purposes under the marks "Crystalite" and "Lucite" at 85 cents per pound, and for the making of dental plates under the names "Vernonite" and "Crystalex" at \$45 per pound. Only two companies distributed Rohm and Haas' product to the dental trade. ${ }^{61}$ The consent judgment entered against Rohm and Haas requires compulsory sale of methyl methacrylate to dental customers. ${ }^{62}$

\footnotetext{
${ }^{67}$ Compare the discussion later on in this article of the use of trade-marks by related companies, infra. Judge Freed likewise held against Timken on its other defenses that the restraints were (I) reasonable, (2) ancillary to Timken's formation of a "joint venture" with the British and French companies, and (3) ancillary to Timken's furnishing technical information and "know-how" to those companies.

${ }^{58}$ See Becchnut Packing Co. v. P. Lorillard Co., 7 F. $2 d$ 967 (C. C. A. $3 d$ I925), $a f f^{\prime} d, 273$ U. S. 629 ( 1927 ).

${ }^{80}$ See Diggins, supra note 39, at 129-r3I. $\quad{ }^{\circ 0} I d$. at 127-128.

${ }^{\circ 2}$ Hearings before the Senate Committee on Patents on S. 2303 and S. 249I, 77th Cong., 2d Sess. 663 et seq. (I942).

${ }^{62}$ Art. VII of Final Judgment in United States v. Rohm \& Haas Co., supra note 45.
} 
In a proceeding in 1936, the Federal Trade Commission found a price discrimination in violation of Section 2 of the Clayton Act in the fact that Goodyear Tire \& Rubber Company gave Sears, Roebuck a lower price than it gave its other customers. The discrimination was made possible only by calling the tires sold to Sears, Roebuck "All State" and "Companion," naming those sold to the rest of the trade "All Weather" and "Pathfinder," and concealing from the general trade the common source of manufacture of all these sets of tires. ${ }^{63}$

The use of "fighting brands" is one of the most ancient of illegal antitrust restraints involving the use of trade-marks. Thus, in United States v. American Thread Company, ${ }^{04}$ a combine was formed in the thread industry which monopolized the sale of threads and removed several brands from the market. However, when an independent manufacturer would begin to build up an appreciable business, the agents of the combined companies would revive one of their retired brands, sell it below the cost of production to customers of the independent manufacturer, and put on "flying squadrons" to handle these "fighting brands." False reports were alleged to have been made, among other matters, that the independents were using infringing brands. In the decree entered in the case, the defendants were enjoined from acquiring the brands of competitors; from using fighting brands or flying squadrons (fighting brands being defined as brands offered at prices lower and on terms more favorable than those asked by the seller for substantially the same threads under different brands or names) $;^{65}$ and from harassing and intimidating by threatening to prosecute for trade-mark infringement. ${ }^{.8}$

\section{Pre-emption of Markets and Uniform Price-Fixing}

Shifting from price discrimination between markets accomplished by trade-marks to the use of marks to pre-empt markets and to promote price uniformity, we come to United States $v$. General Electric Company, the only litigated case, besides Tim$k e n$, involving trade-mark abuse in contravention of the Sherman Act. ${ }^{07}$ In this case, General Electric agreed to let Westinghouse use the "Mazda" mark, but declined to let its other patent licensees do so. In addition, General Electric and Westinghouse persuaded public bodies to include in their specifications the requirement that lamps to be furnished those bodies be "Mazda" or "Mazda or equal," a provision which the court held was designed to exclude, and had the effect of excluding, competitors from the municipal market, and therefore violated Section I of the Sherman Act.

It is a truism that uniform price fixing, and the adoption of uniform distribu-

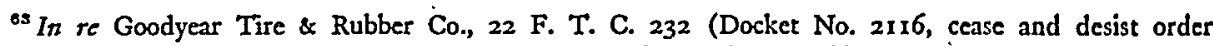
entered March 5, 1936). Later reversed sub. nom. Goodyear Tire \& Rubber Co. v. Federal Trade Commission, ror F. 2d 620 (C. C. A. 6th 1939), cert. denied, 308 U. S. 557 (1939).

o4 D. N. J., Eq. No. 312, consent judgment entered June 2, 1914.

"See Arts. VI(c), (g), (h), and (k) of the consent judgment, stupra note 64 .

or The complaint, it may be noted, charged sales "below cost."

- ${ }^{2}$ United States v. General Electric Co. (D. N. J. Civ. Action No. 1364, Jan. 27, 194I). Note particularly paragraphs 307 to 310 , inclusive. The opinion is reported in 82 F. Supp. 753 (1949). 
tion and production policies, are possible only where the product is of a substantially uniform nature. A trade-mark can frequently be a guarantee that a product is of such uniform nature. In fact, this was the way trade-marks functioned in the lumber industry, in which there have been several antitrust cases. Characteristic is the case brought against the Southern Pine Association and its members, where the trade-mark "SPA" was used to indicate that the lumber had been graded and inspected by the association. ${ }^{68}$ All of the "big mills," which produced 47 per cent of the total production of southern pine lumber but constituted only 4.2 per cent of the number of mills, were members of the association and subscribers to its grading and marking service. The vast majority of the "small mill" operators, consisting of 95.8 per cent of the mills and producing 53 per cent of the total production, were neither members nor subscribers. The association so formulated and administered its grading and grade-marking rules than an unfair competitive advantage was given to the products of its members. As in the case of the Mazda lamp, extensive campaigns were conducted to have localities use only association trademarked lumber for building construction. The Southern Pine Association was successful in preventing competing trade groups from getting public recognition for their own trade-marks. Lumber manufacturers, under the compulsion of losing their trade, were compelled to subscribe to the association's grading and marking services. These manufacturers were obligated to comply not only with the grading and inspection rules of the association but also with distribution and production policies, designed to fix uniform prices for lumber, which were considered by the Department of Justice violative of the antitrust laws. The decree entered in the civil case against the Southern Pine Association provided for the erection of an autonomous bureau, to be separate from the association and to be known as the Southern Pine Inspection Bureau, which was to carry on all grading, standardization, inspection, and grade-marking activities. The services of this bureau were to be available at all times on equal terms to all manufacturers of southern pine without discrimination and without any requirement that they join the Southern Pine Association or any other trade association. The judgment has numerous detailed provisions designed to insure non-discriminatory functioning on the part of the bureau. Charges to be made by the bureau for services were to be fixed to cover actual cost, and were to be assessed against subscribers without regard to their membership in any trade association. The bureau had its own mark, which was to be available to all subscribers complying with the bureau's rules with respect to standard grades. In other words, in order to cure the abuse of an ordinary trade-mark, which had resulted in antitrust violation, there was established for the southern pine industry what was in effect a certification mark. ${ }^{69}$

\footnotetext{
${ }^{68}$ United States v. Southern Pine Association (E.D. La., complaint and decree entered Feb. 21, 1940). For comparable illicit use of the grading and marking function, see United States v. Western Pine Association (S. D. Calif., Civ. Action No. $1389-\mathrm{RI}$, complaint and decrce entered Feb. 6, 1941); United States v. National Lumber Manufacturers Association (District of Columbia, Civ. Action No. I1262, 'complaint and decree entered May 6, I94I).

${ }^{\circ 0} \mathrm{Cf}$. discussion of certification marks, infra.
} 


\section{E. Adjuncts to Quantity Control}

It is another self-evident proposition that any method of identifying a product contributes to counting it. Voluntary, direct production-limitation schemes have gone out of fashion because it has always been recognized that they violate the antitrust laws; the current methods of limiting production are to limit the number of competitors who engage in an industry, or to limit the industrial capacity of the industry-indirect methods of accomplishing the objective of production limitation that are harder to cope with than direct methods. However, in the United States Pipe \& Foundry case ${ }^{70}$ patent license agreements provided for the limitation of production by the manufacturers of centrifugally cast iron pressure pipe by imposing a penalty on a patent royalty basis on pipe produced above a fixed amount. One of the methods capable of use in enforcing this limitation was the requirement that the pipe manufactured by the so-called "deLavaud" process, by which most of the pipe in the industry was manufactured, be stamped with the name "deLavaud." While this was ostensibly desired as a method of quality control, it could have had considerable advantage as a quantity control. The consent judgment entered in this case provides that the defendants be restrained from conditioning a patent license or immunity, or a disclosure of technical information or data, or a sale or lease of pipe manufacturing machines, upon the requirement that the other parties to the transaction agree to adopt and use trade-marks or trade names owned or controlled by any defendant. ${ }^{71}$

\section{F. Trade-Marks as General Adjuncts to Domestic Monopoly}

It is impossible, of course, to determine in all cases when a potent trade-mark is the creature or (as possibly in the cases of tobacco and soap) the cause of an alleged monopoly. When, however, the problem arises of awarding antitrust relief necessary to dissipate the effects of a monopoly, that question becomes academic, because trade-mark relief can be as effective to that end as other types of relief. Furthermore, the mere existence of a monopoly over the manufacture or distribution of a product necessarily confers upon the trade-mark or name for that product that quality of genericness and indispensability for describing the product that leads courts to declare the mark or name to be in the public domain. Thus, in the A.B. Dick case provision was made for the dedication of the trade-mark "mimeograph" both in this country and in foreign countries and for debarring the defendant from using the trade-mark in any way to interfere with imports or exports. ${ }^{79}$ In United States v. Gamewell, the defendant was charged with acquiring trade-marks as well as patents on fire-alarm equipment for the purpose of securing and maintaining a monopoly of the manufacture and sale of such equipment, and of filing or

${ }^{70}$ United States v. U. S. Pipe and Foundry Co. (D. N. J. Civ. Action No. 10772). The summary in the text takes no account of the trade-mark feature of U. S. Pipe and Foundry Company's lease-license agreement with a Mexican corporation.

${ }^{71}$ Id., Art. V(e) of Final Judgment of July 2r, 1948.

${ }^{72}$ United States v. A. B. Dick Co. (N. D. Ohio, Civ. Action No. 24188, entered March 25, 1948), Arts. III.I I (b), III.I2(c), VII.I. 
threatening to file patent and trade-mark infringement suits for the purpose of eliminating others from the selling of fire-alarm equipment. ${ }^{73}$ In the consent judgment in that case, Gamewell was enjoined from threatening to bring or bringing any suit based on seventeen enumerated trade-marks, except such as might be necessary to insure that other users of those marks indicate the source of origin of the trade-marked products. ${ }^{74}$

With these judgments may be compared the consent judgment entered recently against the American Optical Company and others, where similar provision was made against the defendants' suing on any of six trade-marks, except for the taking of steps necessary to prevent deception of the public and to indicate source of origin. ${ }^{75}$ In the American Optical case, the dedication was a corollary to depriving the defendants of their patent monopoly, rather than an effort to divest a defendant of any other economic monopoly. The "Numont" eyeglass frame patent monopoly, for example, was used as the basis for industry-wide patent licenses fixing the manufacturers' sales price for "Numont" frames. In addition to this, the patent license imposed the additional requirement that the licensee manufacturers use the trade-mark "Numont," so that the resale price of "Numont" frames might also be fixed. Thereby there was achieved for the industry both horizontal price-fixing (through the patent licenses) and vertical price-fixing (through resale price maintenance contracts based on trade-marks). This, plus the possibility that the patent restraint might be revived in the shape of similar trade-mark control, was the basis for the additional provision in the judgment prohibiting the defendants from requiring patent licensees to use any specific trade-mark. ${ }^{76}$

IV

\section{The Lanham Act}

The proponents of the Lanham Act have stressed that the purpose of the Act is to promote competition, and that the antitrust laws are completely unaffected. ${ }^{77}$ There is no indication in the statute to the contrary. In fact, specific language in the statute deprives trade-marks used to violate the antitrust laws of enforceability. ${ }^{78}$ Thus there would seem to be every assurance that no judge savoring the full flavor of the Line Material and Paramount decisions, with their insistence on the overriding

${ }^{73}$ See paragraphs ro(c) and (i) of complaint (D. Mass., Civ. Action No. 6150).

${ }^{74}$ Art. V(E) of Final Judgment, entered March 22, 1948.

${ }^{75}$ United States v. American Optical Co. (S. D. N. Y., Civ. Action No. 10-39I) Art. IX of Final Judgment of September 17,1948 .

${ }^{70}$ Id., Art. XI. The resale price maintenance contracts were, of course, also required to be canceled. Id., Art. XII.

77 "Trade-marks, indeed, are the essence of competition, because they make possible a choice between competing articles by enabling the buyer to distinguish one from the other." H. R. No. 219, 79th Cong., Ist Sess. 3 (1945); Sen. Rep. No. 1333, 79th Cong., 2d Sess. 4 (1946).

${ }^{78}$ Section $33(b)(7)$, 60 STAT. 438,15 U. S. C. $8 \min ($ b) (7) (1946). This is farther than the Supreme Court went with respect to abused patents in the Hartford-Empire (323 U. S. 386 (I945)) and National Lead ( 332 U. S. 319 (1947)) cases. For the division of views as to the legal impact of this provision, sec infra. 
scope of the antitrust laws, would permit trade-marks to become an instrumentality for making a breach in the coverage of the antitrust laws. ${ }^{78^{a}}$ Why then any anxiety?

The answer is that successful antitrust policy must be both preventive and keyed to the problems of enforcement. Thus, there can be many a slip between the legislative chalice and the judicial lip. Policy may be safe and solid at the Olympian level where it is on occasion enunciated-the Congress and the Supreme Courtand yet become a bit bedraggled and haphazard at the level of practice where it must continually live. Congress has arguably given additional support in the Lanham Act to the view that a trade-mark is an independent, substantive property right, rather than a mere signpost keeping would-be tort-feasors from engaging in unfair competition. One may rely on antitrust defendants who use trade-marks to support that view, for it is not unusual for such defendants to defend their attacked trade restraints by asserting them to be proper exercises of their property rights. Furthermore, one of the most characteristic features of an antitrust conspiracy is its capacity to make illicit use of innocent instrumentalities such as trademarks. ${ }^{79}$ Since the major obstacle to antitrust enforcement has not been unfavorable court judgments but the attrition of cumbersome and dilatory court proceedings, any legislation which, even by unwarranted inference, can be included in an antitrust defendant's pleadings or briefs deserves careful watch.

Moreover, the basic social problem of antitrust is only fragmentarily depicted in court litigations. A legal development may not rise to the dignity of inclusion in a formal antitrust proceeding, and yet have serious potentialities for the stifling of competition and the spread of monopoly. Thus, it becomes pertinent to this discussion to raise such questions as these: Are the protections of the Lanham Act of a kind which in the long run inure primarily to the benefit of the large national corporations, or will they be equally beneficial to small businesses? To what extent will private suits involving trade-marks and trade names have an influence on competition over and above their role in conserving whatever "property" values the litigants think are inherent in the mark? Can the procedures and policies of the Patent Office mitigate undesirable anti-competitive effects of trade-mark protection? How much of the traditional common-law trade-mark philosophy in favor of competition will permeate the interpretation of the Lanham Act, and thereby still further lessen the probability of anti-competitive use of trade-marks?

It is in the light of questions such as these that we should analyze the Lanham Act. Basically, it is the writer's view that the conventional judicial theory of trademarks as indications of source of origin is, in the ordinary case, not inimical to competition. If the Lanham Act is interpreted in accordance with that conventional

${ }^{782}$ Since this article was prepared, Judge Freed, in the Timken case, supra note 56 , has stated that the legislative history of the Lanham Act clearly discloses that the Act was not intended to undermine the antitrust laws.

${ }^{79}$ An illegal conspiracy may consist of legal parts. Aikens v. Wisconsin, 195 U. S. 194, 205-206 (1904); Swift and Company v. United States, 196 U. S. 375, 396 (1905); United States v. American Column and Lumber Co., 263 Fed. 147, 15I-152 (W. D. Tenn. 1920). 
theory, then its untoward effects on competition will be minimized. On the other hand, if the Lanham Act is construed to involve any substantial redefinition of the orthodox trade-mark concept, its effect will be anti-competitive. In favor of not giving the ordinary post-Lanham Act mark any broader legal scope than the preLanham Act mark is the fact that the Act has validated a new species of mark, ringed around with special safeguards, to assume the so-called quality or "guarantee" function-the certification mark. Also the mere fact that a trade-mark, psychologically speaking, may generate a wider chain of associations than the "source of origin" is no reason why the law should afford these other associations legal recognition. Law, after all, is a normative discipline, and is under no obligation to be a general register of psychological sensations and social reactions. To say, therefore, that a trade-mark connotes to a buyer quality or workmanship is to record one of many possible observable reactions to the use of the mark, but except with respect to certification marks it is a reaction with little legal significance.

In the interests of summarily covering a wide legislative terrain with some semblance of clarity, seemingly dogmatic answers may be given to some questions. However, this is a purely surface matter, because we are dealing with a statute that is inspired by divergent philosophical theories of trade-mark protection which were not effectively reconciled, is unclear in many spots, and has thus far been the subject of very little judicial interpretation. Obviously such a statute permits of little dogmatism.

\section{A. New Types of Marks Subject to Registration-Incontestability}

Much has been made in earlier sections of this article of the parsimony of the courts in permitting the exclusive appropriation of a mark by would-be appropriators. The Lanham Act shows a surface intention to let down the bars. Thus Section 2 lays down as a general principle that "no trade-mark by which the goods of the applicant may be distinguished from the goods of others shall be refused registration on the principal register on account of its nature." Furthermore, the Act provides that trade-marks used in connection with services may be registered, thereby giving protection to "audible" marks such as radio slogans and advertisements. The registration of collective and certification marks is also provided for. Registrability has been expanded, it has been argued, for marks that are geographical, descriptive (or even misdescriptive), or names or surnames, both under specific language relating to such marks and by virtue of Section 2(f), which permits the registration of marks otherwise unregistrable if such marks have "become distinctive of the applicant's goods in commerce." ${ }^{\text {80 }}$ Furthermore, for the first time it is recognized (in Section 23) that the marks on the Supplemental Register, which is a continuation of a similar register under the Act of 1920, may include not only the conventional types of trade-marks and trade names but "any ... package, configuration of goods, name, word, slogan, phrase . . . numeral, or device ..." -lan-

${ }^{\circ}$ Walter J. Derenberg, Registrability Under the Lanham Act I3-i7 (Practising Law Institute Lecture, Oet. 16, 1947). 
guage which may lead, in the words of an eminent commentator, to "new and harassing monopolies." 81

Now, of course, the fact that a symbol may be registered by one person does not of itself legally imply that other persons will be excluded from the use of that symbol, although there is a psychologically minatory feature about registration; the main impact of the Lanham Act on competition will be the new legal effectiveness, if any, given registration. First, registration is made constructive notice of the registrant's claim of ownership of the mark (Section 22). Second, cancellation proceedings, except for certain specified grounds, must be brought within five years of the registration (Section $\mathrm{I}_{4}$ ). ${ }^{82}$ Third, and most important, in the absence of a cancellation proceeding, the mark becomes incontestable at the end of a five-year period except for certain provisos (Section 15 ).

The possible effect of these provisions on, let us say, a young and struggling business using locally in Arizona or California a mark that is similar to one used by a large national corporation is obvious. Trade-mark counsel being something of a luxury for a small business, it seems reasonable to suppose that the national corporation will register the mark first, even though it be a Johnny-come-lately to the use of the mark. The Arizona corporation may for five years remain oblivious to such registration or of its right to cancel the registration, in which event it becomes foreclosed from the right to use the mark in territory subsequently developed by it. If, within the five-year period, it stumbles upon the idea that it should canvass the Register or bring cancellation proceedings, it must procure representation in Washington, regardless of the state of its pocketbook, regardless of whether the national corporation is doing any buisness in its area or not, and regardless of whether the national corporation is even dealing in the same commodity as the local corporation. For an incontestable registration arguably gives the owner of the registered mark exclusive rights throughout the United States, ${ }^{83}$ and, in the current state of the law, may subject to suit a non-registering user of the mark even where he uses the mark on a product that the registrant does not produce or even intend to produce. ${ }^{84}$

${ }^{81}$ HandLer, op. cit. stpra note 29, at 233. Molengraaff, The Nature of the Trade-Marl, 29 Yale L. J. 303 (1920), has pointed out that the properties and qualities of an object, such as weight, color, shape, size, and character cannot be used as a trade-mark because they form part of the goods and make them unlike other goods. Hence, such attributes do not distinguish the object from similar goods. Id. at 304. He also pointed out that a covering or envelope, or label or ticket, cannot be a trade-mark. Id. at 305-306.

82 The rule has been that laches is no defense to a cancellation procecding. Proctor \& Gamble Co. v. J. L. Prescott Co., 77 F. 2d 98, ror-ro2 (C. C. P. A. 1935).

${ }^{83}$ Judge Wyzanski has even held that a registrant may enjoin a purely intrastate use of a mark on the ground that such local use may adversely affect interstate sales. Cole of California, Inc. v. Collette of California, Inc., 79 U. S. P. Q. 267 (D. Mass. 1948). This was contrary to what the Supreme Court had held under the 1905 Act. U. S. Printing and Lithographic Co. v. Griggs, Cooper \& Co., 279 U. S. 156 (1929).

${ }^{84}$ See Hoge, Trademark Infringement I98-r99 (Practising Law Institute Lecture, Jan. 15, 1948); Mrdoleton, Trends in Judictal Interpretation 250-25I (Practising Law Institute Lecture, Jan. 22, r948). Middleton points out, however, that the Lanham Act is still not broad enough on this point to include the so-called "sponsorship" and "dilution" theories. If this interpretation of $\$ 32(1)$ of the Lanham Act is-correct (which is doubtful), it would represent ultimate triumph for the vicws of 
The common law, it may be noted, had not been friendly to the notion that the owner of a trade-mark could pre-empt the use of that mark for all of interstate commerce if he himself used it only in a limited geographical area, ${ }^{85}$ or if he used it with respect to a so-called noncompeting commodity or a commodity differing significantly from that of an alleged infringer. ${ }^{86}$ There would seem to be something anti-competitive about allowing a resource, symbolic and conceptual though it may be, to be monopolized by people who do not exploit it themselves yet may prevent its exploitation by others. ${ }^{87}$

The pre-emptive scope given a registered mark is accentuated by the tendency on the part of many national corporations to register a great number of marks, more than they really need. Thus some corporations register "alternative" marks, which are in fact designations of different grades of the same article and therefore, in the view of some critics, should not be registered at all. Other large corporations tend to register "family trade-marks" or "associated marks," e.g., a series of a dozen or so marks such as "Wheaties," "Oaties," etc. This also is a trend of which serious commentators have been critical. ${ }^{88}$

While it is possible to interpret the Lanham Act as adding to the general defenselessness of small business (and in fact the outlook of the Justice Department and F. T. C. representatives at the Congressional hearings was inky in its pessimism), a more optimistic outlook may also be justified. There is no necessary correlation between the administrative registration or lack of registration of a trade-mark and its validation and enforcement by the courts. ${ }^{89}$ The Second Circuit has, even since the passage of the Lanham Act, repeated the prevailing doctrine that registration of a mark confers only procedural advantages and does not enlarge the registrant's

Schechter, supra note to. Possibly the internal procedures of the Patent Office may constitute a limiting safeguard. Rule 16.3 provides that original applications for registration shall be limited to a single one of 50 specified classes of products (see also Rule $x 6 . x$ ). The fee for each original application is $\$ 25.00$ (Rule 2.I), so efforts to cover several classes may prove quite costly. However, classification does not limit or extend the applicant's rights (Rule I6.1).

Q6 The common-law rule was that the mark must connote the owner's product in a given area before he could prevent its use by others in that area. Columbia Mill Co. v. Alcorn, I5o U. S. $460,463-464$ (1893); Canal Co. v. Clark, $x_{3}$ Wall. $3 \mathrm{II}, 323$ (U. S. $187 \mathrm{I}$ ); U. S. Printing and Lithographic Co. v. Griggs, Cooper \& Co., 279 U. S. 156 (1929); United Drug Co. v. Rectanus Co., 248 U. S. 90, 98 (I9r8). Each trade-mark owner owns the mark in the territory he occupies. Hanover Star Milling Co. v. Metcalf, 240 U. S. 403 (rg16).

${ }^{80}$ See American Steel Foundries v. Robertson, 269 U. S. 372, 380 (I926); Dwinell Wright Co. v. White House Milk Co., I32 F. $2 \mathrm{~d} 822,824$ (C. C. A. 2 d I943) (coffee and tea sufficiently related to milk). The problem has always been to determine when a manufacturer is associated with a commodity he does not produce. Obviously, as Judge Learned Hand points out, it is no harm to the seller of a steel shovel to have his mark used on a lipstick. See L. E. Waterman Co. v. Gordon, 72 F. 2d 272, 273 (C. C. A. 2d 1934) (carry-over from fountain pens to razor blades).

${ }^{\mathrm{st}}$ The dangers of concurrent registration as a prelude to division of territories or fields have already been explored. The Lanham Act treatment of the problem of concurrent registration is set forth infra.

${ }^{88}$ Derenberg, op. cit. supra note 80, at 8-9; AbT, Trademarks from the Advertiser's Point of VIEW 287 (Practising Law Institute Lecture, Oct. 30, 1947). See also Albany Perforated WrappingPaper Co. v. Hoberg Co., 102 Fed. 157, 159 (C. C. E. D. Wis. 1900).

${ }^{80}$ Sce E. F. Prichard Co. v. Consumers. Brewing Co., I36 F. 2d 512, 518 (C. C. A. 6th 1943), and, cases therein cited. 
substantive rights; $;^{90}$ that the test of trade-mark infringement differs little, if any, from the test of unfair competition; ${ }^{91}$ and that the test of unfair competition is whether the public is likely to be deceived, $i . e$., whether it thinks that the goods are the goods of another person. ${ }^{92}$ The courts have given enforcement, because of a derived secondary meaning, to trade-marks which were denied registration because of their descriptive or geographical characteristics; ${ }^{93}$ conversely, they have denied validity to marks of indisputably ancient origin and registration. ${ }^{94}$ There is therefore no certainty that even the Lanham Act's permission to register marks which, though otherwise unregistrable, have become distinctive of the registrant's goods, will bear any substantive judicial fruit.

Furthermore, given a considered and conservative interpretation by the Patent Office and the courts, the notice and incontestability features of the statute may lose a considerable part of their anti-small-business sting. Thus, the statute itself allows for cancellation and for exceptions to the rule of incontestability for abandonment, fraud, misrepresentation, etc., which have led to considerable doubt as to whether incontestability means very much. A recent article points out twenty-one different grounds in the Act for contesting a mark; $;^{95}$ the National Association of Manufacturers Subcommittee on Trade-marks is clamoring for strengthening amendments to the Act; ${ }^{96}$ and even optimists about incontestability will concede that over-popularization or misuse of a mark deprives it of its incontestability. ${ }^{97}$

${ }^{\circ 0}$ Best \& Co. v. Miller, 167 F. 2d 374 (C. C. A. 2d 1948) ("Lilliputian Bazaar" case). For cases prior to the Lanham Act stating the prevailing doctrine, see Armstrong Co. v. Nu-Enamcl Corp., 305 U. S. 315, 322, 324 (1938); Emerson Electric Mfg. Co. v. Emerson Radio \& Phonograph Corp., IO5 F. 2d go8-91o (C. C. A. $2 d$ r939), cert. denied, 308 U. S. 6I6 (1939); George W. Luft Co. v. Zande Cosmetic Co., 142 F. $2 \mathrm{~d} 536,54 \mathrm{I}$ (C. C. A. $2 \mathrm{~d}$ 1944), cert. denied, 323 U. S. 756 (1944). Stated another way, a valid registration confers on the registrant only the right to sue in a federal court, a right which would usually be his under the diversity jurisdiction in any event. Sec Standard Brands v. Smidler, supra note 13, at 36; Industrial Rayon Corp. v. Dutchess Underwear Corp., 92 F. 2 d 33 (C. C. A. 2d 1937).

${ }^{01}$ See, in addition to the Best \& Co. and Armstrong cases, stupra, American Stecl Foundrics v. Robertson, 269 U. S. 372, 380 (r926); Harky D. Nims, The LAw of Unfair Competitton and TradeMarks $8 \mathrm{et} \mathrm{seq.} \mathrm{(4th} \mathrm{cd}$. 1947); Handler and Pickett, Trade-Marks and Trade Names-An Analysis and Synthesis, 30 CoL. L. Rev. 168, 758 (1930).

${ }^{02}$ S. C. Johnson \& Son v. Johnson, II6 F. 2d 427, 429 (C. C. A. 2d 1940); Eastern Wine Corp. v. Winslow-Warren, Ltd., supra note 15, at 960; General Finance Loan Co. v. General Loan Co., I63 F. 2d 709, 712 (C. C. A. 8th 1947). An intention to deceive, if futile, is not actionable. See Kann v. Diamond Steel Co., 89 Fed. 706, 7I2 (C. C. A. 8th I898).

${ }^{03}$ Barton v. Rex-Oil Co., 2 Fed. $2 d 402$ (C. C. A. 3d 1924) ("Dyanshine"); Mellheny Co. v. Gaidray, 253 Fed. 673 (C. C. A. 5th r918); Mcilheny Co. v. Bulliard, 265 Fed. 705 (D. La. 1920); Mcllheny v. Trappey, II T. M. Rep. 397 (D. La. I92I), affd, 28 I Fed. 23 (C. C. A. 5th 1922), all dealing with "Tabasco" sauce.

D\& Compare two recent infringement suits, one dealing with a validly registered mark in use since 1879, where the courts denied relief on the ground that the mark was descriptive. National Nu-Grape Co. v. Guest, 164 F. 2d 874 (C. C. A. roth 1947), cert. denied, 333 U. S. 874 (1948); Best \& Co. v. Miller, supra note go.

${ }^{\circ 5}$ Williamson, Trademarks Registered Under the Lanham Act Are Not "Incontestable," 37 T. M. Rep. 404 (1947).

${ }^{\circ 0}$ See report of March 24, 1948. These amendments are embodied in the measure introduced by Senator Hawkes at the last session of Congress, S. 1919, 80th Cong., Ist Sess. (1947).

${ }^{87}$ Derenberg, The Status of Existing Trademark Registrations Under the Nctv Trademark Act of 1946, 3 Food, DruG, AND Cosmetic L. Q. 270, 277-278 (1948). 
The proponents of the Lanham Act testified that, where a mark loses its significance as an indication of origin and becomes generic, it would be considered abandoned under the Act, which would mean that it could not become incontestable. ${ }^{08}$ Supplementing this, the Lanham Act incorporates a Senate amendment to the effect that "no incontestable right shall be acquired in a mark or trade name which is the common descriptive name of any article or substance, patented or otherwise." Circuit has vigorously denounced the monopolistic implications inherent in the attempt by the owner of a trade-mark ("Sunkist") used on fruits and vegetables to ban its use on bread. ${ }^{100}$ There have been other expressions of judicial distaste for the application of a trade-mark to a commodity differing from that of the trade-mark owner. ${ }^{101}$ Even from Judge Clark, who has taken the view in dissent that the Lanham Act has enlarged the common law of trade-marks, there seems to be a discernible antipathy to the notion of trade-marks on "shapes" of objects. ${ }^{102}$

There are other substantial protections in the language of the statute itself. Defenses are specifically provided against trade-mark infringement suits (Section 33). The abuse of marks in certain critical situations is carefully guarded against, e.g., certification marks, patented articles, use by related companies. The Lanham Act itself is an unclear and ambiguously worded statute, and contains words of broad content which the courts may interpret in accordance with the traditional procompetitive policy of the common law in the past. To say, however, that the hazards to small business are problematic and psychological in character, and that the courts are ultimately there to mitigate those hazards, is not to rob them of their ponderability.

We now pass to specific classes of marks that were possible instrumentalities of antitrust abuse and examine how they are handled in the Lanham Act.

${ }^{08}$ See testimony of Daphne Robert in Hearings before a Subcommittee of the Senate Committee on Patents on H. R. 82, 78 th Cong., 2d Sess. 100 (1944); testimony of Robert W. Byerly in Hearings before the House Committe on Patents on H. R. 82, 78th Cong., Ist Sess. 27 et seq. (1943); testimony of Wallace H. Martin, id. at 34. But of. testimony of Arthur T. Vanderbilt, id. at 21 et seq. Handler, stupra note 29, at $23 \mathrm{I}$, raises the doubt that $\$ 45$ of the Lanham Act may so define abandonment as to preclude the cancellation of marks which lose their distinctiveness through no fault of the registrant.

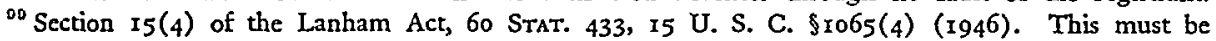
distinguished from the Senate amendment relating specifically to patented articles.

${ }^{100}$ See California Fruit Growers Exchange v. Sunkist Baking Co., 166 F. 2d 97r, 974 (C. C. A. 7 th 1947). The court also stressed that confusion as to source of origin was essential to constitute infringement of the mark under the Lanham Act. Id. at 973. The defendant's mark, it may be noted, was registered only in lowa and Illinois, whereas the unsuccessful plaintiff's mark had been registered in the Patent Office.

${ }^{102}$ See S. C. Johnson \& Sons v. Johnson, supra note 92; Dwinell-Wright Co, v. White House Milk Co., I32 F. 2d 822, 825 (C. C. A. 2d I943); Durable Toy \& Novelty Corp. v. J. Chein \& Co., I33 F. 2d 853, 855 (C. C. A. 2d 1943); National Fruit Products Co. v. Dwinell-Wright Co., 47 F. Supp. 499 (D. Mass. 1943), $a f ' d$, r 40 F. 2d 618 (C. C. A. Ist 1944); Zlinkoff, Monopoly Versus Competition: Significant Trends in Patent, Anti-trust, Trade-Mark, and Unfair Competition Suits, 53 YALE L. J. 5I4, 539 (1944).

${ }^{102}$ See his opinion for the court in Lucien Lelong, Inc. v. Lander, 164 F. $2 d 395$ (C. C. A. $2 d$ I947). 


\section{B. Certification Marks}

One class of marks that has been given special statutory sanction by the Lanham Act consists of certification marks. These, roughly speaking, are "marks used upon or in connection with the product or services of one or more persons other than the owner of the mark to certify regional or other origin, material, mode of manufacture, quality, accuracy or other characteristics of such goods or services ..." (Section 4). Because certification marks were susceptible of abuse as to consumers and had been a vehicle of antitrust violation, their introduction into the Lanham Act aroused considerable apprehension. This apprehension has been largely, if not completely, met by a Senate amendment providing that a certification mark can be canceled at any time if the owner does not control or cannot legitimately control the use of the mark, or engages in the production or sale of the goods or services on which the mark is used, or permits the use of the mark in any way other than as a certification mark, or discriminates against applicants for use of the trade-mark in the certification of that applicant's goods and services. Such cancellation proceedings can be initiated, as can all cancellation proceedings, by "any person who believes that he is or will be damaged by the registration of a mark"; however, the Federal Trade Commission is also authorized to bring cancellation proceedings. In view of the historic role of that Commission in policing the fraudulent and deceptive use of trade-marks, this is an important provision. The requirement that the owner "legitimately" control the use of his mark means that no rights inhere in a mark where such control is a consequence of an illegal cartel agreement or other antitrust practices, as in the General Electric case. ${ }^{103}$ Furthermore, the availability of the certification to all whose products conform to certain standards or conditions is a strong guarantee against the restrictive and anti-competitive use of the mark, provided of course that the owner of the certification mark operates in good faith. In this connection the reader will wish to refer to the practices complained of, and the relief awarded, in the Southern Pine Association case. ${ }^{104}$

\section{Concurrent Registrations}

Another source of anticipated antitrust abuse was Section 2(d) of the Lanham Act, providing for the concurrent registration of "the same or similar marks to more than one registrant when they have become entitled to use such marks as a result of their concurrent lawful use thereof in commerce." In addition to requiring that the concurrent use be "lawful," Section 2(d) provides that the Commissioner of Patents or a court determine that confusion or mistake or deceit would not result from such registration, and authorizes the Commissioner to prescribe conditions and limitations as to the place and mode of use of the trade-marks. Nevertheless, in view of the way in which concurrent use of a mark internationally had promoted international divisions of territories and fields, it was felt that pcrmitting the concurrent registration of the same mark within the United States would result 
in domestic divisions of territories and fields. Thus far, very little effort has been made to take advantage of the provision. Perhaps the thorough ventilation, in the Congressional hearings and in the literature, of the possibility of abusing the process of concurrent registration has been as effective as a more detailed statutory effort to foreclose those possibilities would have been. Another reason for the small number of concurrent registrations may have been the narrow interpretation given the statute and the technical problems attendant upon such registration. ${ }^{105}$

\section{Patented Articles}

A patent on an article confers on the patentee the right to exclude all others from the manufacture and sale of the article, and the exercise of that right to exclude means that whatever name the patent holder gives to his article (e.g., linoleum, kerosene, cellophane) becomes, for at least seventeen years, the name by which that article is known to the general public. It is therefore a sound rule that does not permit a patent monopoly of quite extensive duration to be transferred into a perpetual one by recognizing a trade-mark monopoly obtained during a period when no one else could manufacture or sell the patented article. The Supreme Court and the legal and literary community has long recognized this, ${ }^{106}$ but the Lanham Act recognized it at the last moment, by incorporating an amendment, originated by Senator O'Mahoney but modified in conference, allowing for cancellation of a mark which has become a common descriptive name of an article or substance on which the patent has expired. ${ }^{107}$ Senator O'Mahoney's original amendment would have imposed a more drastic election on the manufacturer - to choose between his patent and trade-mark monopoly ${ }^{108}$ _but the amendment as finally adopted does ameliorate the situation by at least recognizing prevailing law.

\section{E. Use of Marks by Related Companies}

On the conventional theory that trade-marks denote source of origin, their licensing has made slight headway with the courts and has been restrictively regarded by even post-Lanham Act commentators. ${ }^{109}$ More recent proposals for licensing stem from the conception that trade-marks guarantee the goods themselves rather

${ }^{100}$ See Derenderg and Merchant, Problems in Registration Procedure (Practising Law Institute Lecture, Oct. 23, 1947). Trade-Mark Counsel for the Patent Office reports that only two or three concurrent-use proceedings have been instituted under \$2(d) of the Lanham Act. Derenberg, The Lanham Trade-Mark Act of 1946,38 T. M. Rep. 831, 850 (1948).

${ }^{100}$ Singer Mfg. Co. v. June Mfg. Co., I63 U. S. I69 (1896); Kellogg Co. v. National Biscuit Co., 305 U. S. III (1938); Amicsite Asphalt Co. of America v. Interstate Amiesite Co., 72 F. 2 d 946 (C. C. A. 3d 1934). For a detailed presentation of the legislative background of the provision, and the federal and state judicial and Patent Office decisions on this point, see Greenberg, The "Patent" Clause of the Lanham Act, $3^{8}$ T. M. Rep. 3 (I 948 ). For a recognition of this by a student of language, see Henky L. Mencken, The American Language Supp. I 341 (1945).

${ }^{107}$ Sec. 14 (c), 60 STAT. 433,15 U. S. C. $\$ 1064$ (c) (1946). This provision should be distinguished from the one which provides that "no incontestable right shall be acquired in a mark or trade name which is the common descriptive name of an article or substance, patented or otherwise." Sec. 15, 60 StAT. 433, 15 U. S. C. $\$ 1065$ (1946).

${ }^{108}$ The Senate version of H. R. 1654 provides for cancellation and free contestability at any time for a mark which "becomes descriptive of a patented article."

${ }^{100}$ Handler, op. cit. supta note 29, at 240-24I; Harky D. Nins, The LAw of UNFar Competition and Trade-Marks $\$ 22$ (4th ed. 1947). 
than the origin of goods. ${ }^{110}$ The Lanham Act for the first time gives specific recognition to marks which serve the guarantee function, i.e., certification marks (Section 4). The question for consideration-and it will continue to be vexing unless its very vexatiousness makes it academic-is whether by Section 5 of the Lanham Act, immediately following the section dealing with certification marks, Congress intended to provide for the licensing of trade-marks.

Section 5 provides that "where a registered mark or a mark sought to be registered is or may be used legitimately by related companies, such use shall inure to the benefit of the registrant or applicant for registration."111 A "related company" is defined as "any person who legitimately controls or is controlled by the registrant or applicant for registration in respect to the nature and quality of the goods or services in connection with which the mark is used."112 Against its common-law background, the provision - seems clearly intended to enable a subsidiary to take advantage of the use of a trade-mark by its parent, and vice versa, ${ }^{113}$ although it assumes an element of "control" by a parent that would appear to be impossible for large corporate complexes like General Motors ${ }^{114}$ and United States Steel. In fact, in a mammoth industrial empire is it not really quite a large legal fiction to assume unity of source of origin? Can one, for example, attribute unitary origin to the products of a giant holding. company like General Motors, engaged in producing a great number of utterly diverse products through a great number of subsidiary corporations and divisions, which announces as its policy the promotion of competition in such matters as industrial styling among its various subsidiary corporations and otherwise strives to foster a really effective decentralization of operations? ${ }^{115}$

Or look at the situation presented by the program of Botany Mills, Inc., a wellknown woolen manufacturer. Botany in the Thirties decided to go into the consumer field, and we now have "Botany Brand" ties, socks, suits, and topcoats. One of the five largest men's clothing firms in the country, and at one time several hundred women's and children's clothing manufacturers, joined with Botany in advertising and marketing their products under a joint label bearing the Botany name. What "source of origin" is pointed to in such circumstances? And then, when Botany Mills decided that it must, to avoid over-producing for the market, cut down its women's and children's clothing manufacturers to a mere two dozen, was not the competitive effect on the dispossessed manufacturers clear? What per-

${ }^{110}$ Schechtcr, The Rational Basis of Trademark Protection, 40 Harv. L. REv. 813 (1927); Isaacs, Traffic in Trade Symbols, 44 Harv. L. Rev. 1210 (1931); Walter Derenberg, Trademark Protegtion and Unfair Trade 36-39 (1936); Ralston Purina Co. v. Saniwax Paper Co., 26 F. 2d 941 (W. D. Mich. 1928).

11160 STAT. 429 , I5 U. S. C. \$1055 (1946).

11260 STAT. 443 , I5 U. S. C. \$1I27 (1946).

${ }^{123}$ Keebler Weyl Baking Co. v. J. S. Ivins' Son, 7 F. Supp. $21 x$ (E. D. Pa. 1934); Ex parte Steel Corp., 24 T. M. Rep. 597 (x934); Vermont Maple Syrup Co. v. Johnson Maple Syrup Co., 272 Fed. 478 (D. Vt. I92I).

${ }^{114}$ See Whitman, "You Can License Your Trademark If-" 38 T. M. Rep. 639-640 (1948).

${ }^{115}$ See Peter F. Drucker, Concept of the Corporation (1946). 
haps may not have been so clear was the fact that the legal reliance of the dispossessed manufacturers on the Botany trade-mark accelerated their economic dependence on Botany Mills. ${ }^{116}$

It is also possible that the provision was intended to give statutory recognition to a few lower-court decisions justifying the "licensing" of a trade-mark by the producer of a fabricated material to a purchaser who transforms it into a finished product (e.g., "Fruit of the Loom" cloth into "Fruit of the Loom" shirts) 117 or by the seller of a product in bulk to a bottler thereof. ${ }^{118}$ In many cases, the so-called licensed trade-mark was wavering on the brink of genericness. ${ }^{110} \mathrm{Be}$ it noted that a mere purchaser for resale of a trade-marked commodity requires no license in order to use the mark. Also that nothing prevents the processor or bottler from informing the public as to the trade-mark of the ingredients or composition of his product. ${ }^{119^{*}}$ These cases hardly justify the notion that the "licensing" of a trade-mark was a wellaccredited institution at common law. Rather they seem based on the fact that, while an ordinary distributor cannot legally or commercially harm an original manufacturer by reselling the identical product which he bought from the manufacturer, a processor or fabricator working on such a product can through lack of skill or care injure the reputation of the original manufacturer and even subject him to suit. $^{120}$ In fact, the general impression is that the licensing of a trade-mark, generally speaking, is against public policy. ${ }^{121}$ Now that the Lanham Act provides for certification marks, we have, as will be shortly pointed out, an instrumentality that will protect the reputation of an original manufacturer from blemish at the hands of the unreliable or negligent processor or fabricator.

The requirements that the use of the trade-mark by a third party and the registrant's control of the trade-mark be legitimate were simply amendments, made by the Senate Patent Committee, intended to avoid any use of a trade-mark to promote an antitrust restraint. ${ }^{122}$ Accordingly, it could be urged that use of the same mark by a parent and its subsidiaries, where the parent-subsidiary industrial complex is a monopoly that should be dissolved, would constitute illegitimate use as well as illegitimate control of the mark. Furthermore, as a recent commentator

${ }^{130}$ Newsweek, Nov. 8, 1948, p. 68.

${ }^{217}$ B. B. \& R. Knight Co. v. W. L. Milner \& Co., 283 Fed. 816 (N. D. Ohio I922); H. Freeman v. F. C. Huyck, 7 F. Supp. 97 I (N. D. N. Y. 1934).

${ }^{218}$ Coca-Cola Co. v. J. G. Butler \& Sons, 229 Fed. 224 (E. D. Ark. 1916); Coca-Cola Co. v. Bennett, 238 Fed. 513 (C. C. A. 8th 19I6); The Coca-Cola Bottling Co. v. The Coca-Cola Co., 269 Fed. 796 (D. Dela. 1920).

${ }_{210}$ Dixic-Cola Laboratories v. Coca-Cola Co., IIy F. 2 d 352 (C. C. A. 4th I94I), cert. denied, 314 U. S. 629 (194r).

110a See Prestonettes v. Coty, 264 U. S. 359 (1924); Champion Spark Plug Co. v. Sanders, 33 I U. S. 125 (1947).

120 This seems to have been particularly true of the Coca-Cola cases.

${ }^{121}$ See note 108 supra. This is on the basis that the licensing of trade-marks tends to destroy their utility as indication of source of origin. Cf. HANDLER, op. cit. supra note 29, at 212; NIMs, op. cit. supra note rog.

${ }^{122}$ Sec Taggart, Staturory New Concepts of Tradenark Ownership 5 (Practising Law Institute Lecture Nov. 13, 1947). 
states, matters which were illegal restraints of trade when they figured in illegal patent license agreements would clearly be equally illegal if they accompanied the use of trade-marks. ${ }^{123}$ In fact, the owner of a trade-mark is in a dilemma not applicable to a patent holder. The common law and Section 5 of the Lanham Act, assuming that they authorize a trade-mark owner to license his mark, would do so only on the basis that he control the "nature and quality" of the goods or services in connection with which the mark is used. Such quality control inevitably restricts the'area of competition, and such restriction of the area of competition, if pushed too far, can involve or facilitate an illegal restraint of trade. ${ }^{124}$ And yet failure to control those goods may constitute an abandonment forfeiting the mark. ${ }^{125}$ Thus there exists doubt as to both the permissibility and the scope of trade-mark licensing.

The following considerations, though, may serve both to resolve that doubt and to give us a socially acceptable interpretation of the Lanham Act. Manufacturers and distributors should, as a general rule, develop their own marks, and not use the marks of others. The only economic need which compels $A$ to apply to $B$ for the use of $B^{\prime} s$ mark is that $B^{\prime}$ s mark is generic or descriptive. If, however, the mark is generic or descriptive, there is no legal or economic justification for such an application; the mark is theoretically free to all. If, on the other hand, a manufacturer desires to convey to the public an assurance of quality or a standard of workmanship, the way to that end is through a certification mark, for which the Act makes specific provision. And, as Section 4 of the Act recognizes, certification marks should not be licensed by one competitor to another, for a person who tries to make or market a competitive article is hardly an unbiased judge of the merits of his competitor's products. In fact, there is considerable likelihood that a manufacturer or distributor will either refuse to license his mark to a competitor for an equally qualified product, or will require, as a quid pro quo for the license, that his competitor conform to other commercial standards and practices than those of quality or workmanship, i.e., price and other trade restraints.

The kind of situation in which the foregoing analysis might have some utility is that involved in the recent case of Triangle Publications, Inc. v. Rohrlich. ${ }^{120}$ In that case, Judge Augustus N. Hand sustained the finding of the lower court that the publisher of the magazine Seventeen could sue the manufacturer of a girdle bearing the same name on a charge of unfair competition. He held that the use of the name "Seventeen" to describe apparel would create a belief in the mind of a teen-age girl that the apparel was advertised or commented on editorially in the

${ }^{123}$ See HandLER, op. cit. supra note 29.

${ }^{134}$ See Whitman, supra note $\mathrm{II}_{4}$, at 640 ; Judge O'Connell, dissenting, in E. I. du Pont de Nemours \& Co. v. Celanese Corp. of America, 38 T. M. Rep. 666, 673 (C. C. P. A. 1948).

${ }^{225}$ Everett O. Fisk \& Co. v. Fisk Teachers' Agency, 3 F. 2d 7 (C. C. A. 8th x924); Circuit Judge Major, dissenting, in Purity Cheese Co. v. Frank Ryser Co., 153 F. 2d 88, 90 (C. C. A. 7th 1946); Judge O'Connell, dissenting, in E. I. du Pont de Nemours \& Co. v. Celanese Corp. of America, supra note 124 .

${ }^{126}$ x67 F. 2 d 969 (C. C. A. $2 d$ 1948). See E. I. du Pont de Nemours \& Co. v. Celanese Corp. of America, supra note 124. 
magazine Seventeen. In short, the magazine was a "source of sponsorship," and its good-will could be damaged if the goods sold by the defendant were inferior to the high quality which the public attributed to goods actually advertised in or commented on by the magazine. Since the plaintiff prevailed on this point, it was not necessary to decide whether the defendant had infringed the registered mark, which the district court had found to be arbitrary, fanciful, and one that had almost immediately acquired a secondary meaning. Judge Frank, dissenting, said that the name "Seventeen" was descriptive; that any secondary meaning attached to it was limited to the magazine; that no confusion was likely between the magazine and girdles, which are a non-competing article; and that there was no finding that the defendant in fact sold goods inferior to those advertised. To this writer it seems that trade-mark law has enough trouble on its hands without espousing a new concept like "source of sponsorship."127 After all, protecting the snob appeal of a medium of mass advertising is something radically different from protecting the snobbery of the consumer. If, however, the idea of sponsorship is to gain recognition in trade-mark law, it should be in connection with certification marks rather. than ordinary marks, accompanied by all the safeguards which the Lanham Act has attached to certification marks.

In an ambiguous and unclear statute, the section on "related companies" is one of the most equivocal provisions. Registrants would therefore do well to proceed cautiously, because the Patent Office has no facilities for probing such delicate and involved issues as "legitimacy" or "restraint of trade."

\section{F. Assignment of Marks}

In this day of mergers and consolidations, any easing of the terms and conditions under which marks may be assigned becomes of considerable significance, because marks may frequently be a most essential element of the merged business. ${ }^{128}$ It was an accepted cliché of conventional trade-mark law that trade-marks, as indications of source of origin, had no significance except as appurtenant to a going business, and so it was assumed that they could be assigned only in conjunction with a going busi-

${ }^{127}$ The approach taken by the Patent Office in Esquire, Inc. v. Knomark Manufacturing Co., 38 T. M. Rep. 486 (1948), seems far preferable. Esquire, on the ground that it had established itself as a leading source of authoritative information and advice on the subject of male grooming, argued that the Esquire mark had acquired a secondary meaning and a "celebrity," and had come to indicate that any merchandise bearing the mark was approved or sponsored by Esquire and met the requirements set by it for good grooming. On this basis, Esquire entered a petition to cancel a trade-mark registration applicd for by Knomark for shoe polish. The assistant commissioner, in upholding the examiner's dismissal of the petition, pointed out that there was no reason why a publication even as well known as Esquire should be treated any differently from any other merchandiser; that its trade-mark rights could be considered only in connection with the trade in which it was engaged, and did not entitle it to preclude the registration of marks by others in connection with other products. (Both the Patent Office and the writer are aware that this was a statutory proceeding for cancellation in the Patent Office and not an equitable action for unfair competition in a court.)

${ }^{228}$ See Decree of Dissolution and Injunction in United States v. Eastman Kodak Co. (W. D. N. Y., Eq. No. A-5I, entered Feb. I, 192I); cf. United States v. National Gum and Mica Co. (S. D. N. Y., Eq. No. 40-276, entered May 27, r927. 
ness, and that "naked assignments" or "assignments in gross" were invalid. ${ }^{129}$ When, therefore, early versions of the Lanham Act provided for the assignability of registered marks "either with or without the good will of the business," as undermining the entire basis of trade-marks and destroying public confidence in them. Even Section io of the Lanham Act, providing that a mark could be transferred in connection with the "good will or part of the good will" of a business, was attacked as a prelude to the indiscriminate hawking of marks and to the creation of a property right in marks unrelated to the protection of the consumer. Putting to one side the delicate and frequently impossible surgery involved in dividing the good will of a concern into parts, ${ }^{131}$ the main difficulty with the provision is its ambiguity. "Good will" is an accordion term. In some cases, where one is dealing with manufacturing enterprises, or businesses the commercial success of which is attributable primarily to their location, good will obviously cannot be transferred except in connection with the transfer of physical property. Once one retreats from that safe ground to the proposition that the transfer of customers' lists and mailing lists are sufficient "good will" to support an assignment of a trade-mark, a subtle verbal transference has taken place. We are in effect passing from a consideration of the factors which justify good will, and justify consumer reliance on the "source of origin," to purely fortuitous factors that give businessmen in the chips a competitive "in." Let us hope, therefore, that the courts will play the accordion of "good will" with restraint.

\section{G. Defenses to Incontestability and Trade-Mark Infringement Proceedings-Use of the Mark to Violate Antitrust Laws}

Until a registered mark has become incontestable, a defendant in an infringement proceeding may prove any "legal or equitable defense or defect" available against the owner of an unregistered mark. However, once the registration has become "incontestable," the registration is conclusive evidence of the registrant's exclusive right to use the mark in commerce. Section 33 (b) of the Lanham Act goes on to list seven specific defenses and defects available against an incontestable mark. The seventh defense, once more a Senate amendment inserted as a specific antitrust safeguard, has probably been the subject of as much speculation as anything else in the statute.

\footnotetext{
${ }^{120}$ Macmahan Pharmacal Co. v. Denver Chemical Co., r13 Fed. $468,474-475$ (C. C. A. 8th 1901); Bulte v. Igleheart Bros., I37 Fed. 492, 498-499 (C. C. A. 7th I905); American Broadcasting Co. v. Wahl, I21 F. 2d 412, 413 (C. C. A. 2d 194I); Nims, op. cit. supra note 109, at 86. Good will is tangible only as an incident, as connected with a going concern or business having a locality or name, and is not susceptible of being disposed of independently Metropolitan National Bank v. St. Louis Dispatch Co., I49 U. S. 436 (1893), cited with approval in Mayer Fertilizer and Junk Co. v. VirginiaCarolina Chemical Co., 35 App. D. C. 425 (1910).

${ }^{180}$ H. R. 904I, 75th Cong., 3d Sess. (1938); H. R. 4744, 76th Cong., Ist Sess. (1939); H. R. $66 \times 8,76$ th Cong., ist Sess. (x939).

${ }_{181}$ Reputation is an indivisible sort of phenomenon and hard to place on the accounting table. For the wrestling of the courts with this problem, see Halliday, Assignments Under the Lanham Act, 38 T. M. Rep. 970 , 973-976 (1948).
} 
The seventh defense is "that the mark has been or is being used to violate the antitrust laws of the United States." Senator O'Mahoney was responsible for subsection (7), and he stated, without contradiction from his Senate confreres, that violation of the antitrust laws is a defense to a suit by the registrant of the trademark. ${ }^{132}$ That is the view adopted by most commentators. ${ }^{133}$ However, Congressman Lanham, in explaining the Senate amendment, has stated that the section was intended not to provide an affirmative defense but merely to destroy the incontestability of a trade-mark and restore registration to its pre-Lanham Act status as prima facie evidence of ownership of the mark. ${ }^{134}$

To this author, Senator O'Mahoney's construction of his own amendment seems the only plausible way to read the subsection, both as a matter of policy and of construction. Even authorities who disagree with the policy of the provision as interpreted by Senator O'Mahoney agree that his is the correct interpretation of the statutory language. ${ }^{135}$ Basic to the position of those who disagree with this appears to be the fear that the comparatively simple enforcement of trade-mark rights may bog down into a complex and involved antitrust proceeding, and a feeling that trade-marks are rarely the "legal, causal, and efficient instrumentalities" of an antitrust restraint. ${ }^{136}$ Now, "legal, causal, and efficient instrumentality to effect a contract or agreement or arrangement which violates the antitrust laws" is remarkable metaphysical verbiage for senators to use in purported explanation of the simple statutory expression, "used to violate the antitrust laws." When one considers that the senators were only trying to describe the antithesis of a "purely physical or coincidental" relation of the trade-mark to the illegal trade restraint, the ponderousness of this language becomes even queerer. It may safely be surmised that the courts, in interpreting Section 33(b) (7), will bear in mind that the other "defenses or defects" listed in Section 33(b), such as fraud and abandonment, are obviously defenses to enforcement of a trade-mark, rather than mere dilution of the evidentiary status of registration as proof of ownership, and will give antitrust violation a similar legal effect. Furthermore, the doctrine of unclean hands constantly confronts the antitrust violator and serves to deprive him of substantive rights, even with respect to that generally more highly respected type of industrial property, the patent. Finally, even where intention and agreement are basic to an antitrust violation, the means used to accomplish or maintain that illegal intention and agreement cannot be dismissed as "purely physical or coincidental" but must likewise be dealt with

13292 Cong. REc. 7873 ( 1946$)$.

${ }^{233}$ Handler, op. cit. supta note 29; Walter J. Derenderg, Preparing for the New Trademarx LAw I4 (Research Institute of America, r946); Lockhart, Violation of the Anti-trust Laws as a Defense in Civil Actions, 31 MrN. L. Rev. 507, 566-568 (1947). Lockhart points out that 533 (a) of the Lanham Act would bring about a similar result, even if $\$ 33(b)(7)$ were not construed in accordance with Senator O'Mahoney's views.

${ }^{134} 92$ Cong. Rec. 7524 (1946); accord, Hoge, op. cit. supra note 84.

${ }^{135}$ See Handler, op. cit. supra note 29; DeRENBERG, op. cit. supra note 133.

${ }^{130}$ For the language used in the Senate debate on this provision, see 92 Cong. Rec. 7636 (r946). 
as integral to the offense. The fact that a trade-mark was not historically at the inner core of a Sherman Act violation does not mean that Section $33(b)(7)$ is inapplicable to it, if the trade-mark subsequently becomes directly involved in such violations.

\section{$\mathrm{V}$}

\section{SUMMARY}

The trade-mark, kept to its sound common-law function as an indicator of source of origin of a product, could, in the general case, probably facilitate competition by differentiating the products of competitors. In special circumstances, however, it becomes a direct vehicle of monopoly power; and not infrequently, as in the case of quasi-fungible commodities where quality competition is minimal, there is doubt whether the differentiation accomplished by trade-marks is economically significant or even relevant. In fact, critics of the trade-mark institution have urged that its functioning on the whole is largely not in the interest of the consumer, thereby leaving to it only a limited role as a stimulus to producers and distributors to compete.

In addition to being the basis for legalizing resale price maintenance, through the Miller-Tydings Act and state legislation, trade-marks have facilitated various types of illegal restraints of trade. The most heavily documented of these types has been the division of territories. However, trade-marks have also been used to bring about illegal division of fields, illegal division of markets and invalid discriminatory price-fixing, pre-emption of markets and uniform price-fixing, quantity control, and, in general, the support of domestic monopoly.

In its original form as it passed the House, the Lanham Act had several features discouraging to the proponents of antitrust policy and to those solicitous for the welfare of small business: expanded types of marks available for registration, covering configuration and contours of packaging; service marks, certification marks, ctc.; incontestability; concurrent registration; use of marks by related companies; assignment of marks, etc. Senate amendments relating to certification marks, the use of marks by related companies, marks on patented articles, and the availability of antitrust violation as a defense to infringement suits have assuaged some of these apprehensions. The future impact of the Lanham Act on competition is uncertain, but it lies within the framework of what the Patent Office and the courts consider to be in the public interest, the restraint which the beneficiaries of the Lanham Act exercise in the enjoyment of their new privileges, and the possibilities for freeing small business from the uncertainty and trepidation that the Lanham Act has created for them. The most articulate and broad-gauged of these influences is the courts, because the basic judicial approach to trade-marks is to regard them as vehicles of both fair and free competition. The hope of antitrust policy in the future is that the courts will pursue their sound doctrines, including the basic one that a trade- 
mark indicates source of origin, and discard unsound developments in the light of contemporary economics and semantics. The courts may bear in mind, for example, that trade-mark recognition is not the only method of rewarding advertising inventiveness; copyrights and design patents are better adapted for this purpose in some respects. Also, if competition is to be adequately protected, sentimental notions that competitors are not entitled to a "free ride" must be carefully scrutinized. ${ }^{137}$ As Mr. Justice Brandeis has remarked, "Sharing in the goodwill of an article unprotected by patent or trade-mark is the exercise of a right possessed by all-and in the full exercise of which the consuming public is deeply interested."138 Assuming, however, that the courts succeed in harnessing the rampant interpretations of the Lanham Act to the chariot of free competition, it would still be necessary to infuse the judicial independence of spirit, which costs judges nothing in cash, into businessmen, whom it sometimes costs dear to try out legal theories.

${ }^{137}$ Judge Frank, dissenting, in Triangle Publications v. Rohrlich, x67 F. 2d 969 (C. C. A. 2 d 1948 ); National Fruit Products Co. v. Dwinell-Wright Co., 47 F. Supp. 499 (D. Mass. I943).

${ }^{138}$ Kellogg Co. v. National Biscuit Co., 305 U. S. III, I22 (I938). 